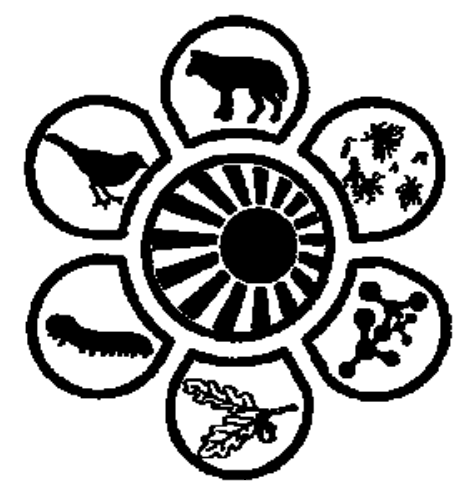

Вісник Дніпропетровського університету. Біологія, екологія.

Vìsnik Dnìpropetrovs'kogo unìversitetu. Seriâ Bìologiâ, ekologiâ

Visnyk of Dnipropetrovsk University. Biology, ecology.

Vìsn. Dnìpropetr. Unìv. Ser. Bìol. Ekol. 2015. 23(2), 134-148.

doi: $10.15421 / 011520$

ISSN 2310-0842 print

ISSN 2312-301X online

www.ecology.dp.ua

\title{
УДК 574.4:591.9(253)+592:591.55 \\ Вплив зімкненості крон дерев і покриття трав'янистих рослин на структуру підстилкової мезофауни широколистяних лісів степової зони України
}

\author{
В.В. Бригадиренко
}

Дніпропетровський національний університет імені Олеся Гончара, Дніпропетровськ, Украӥна

Здійснено аналіз підстилкової мезофауни широколистяних лісів на території Дніпропетровської, Запорізької, Миколаївської, Донецької областей України у 339 природних лісових екосистемах у 2001-2014 рр. Зімкненість крон дерев достовірно не впливає на чисельність підстилкової мезофауни та кількість видів безхребетних у підстилці. Індекси різноманіття Шеннона та Пілоу мають тенденцію до підвищення у градієнті зімкненості крон дерев (від менше 50\% до 90-100\%). Відносна чисельність сапрофагів і зоофагів мінімальна (медіана $18 \%$ та 3\%) у лісових екосистемах із розрідженим наметом, має тенденцію до зростання у лісах із зімкненим деревостаном (40\% та 18\%). Відносна чисельність поліфагів у мезофауні, навпаки, в таких умовах зменшується з $82 \%$ до $27 \%$. Кількість видів кожної трофічної групи достовірно не змінюється у градієнті зімкненості крон дерев у широколистяних лісах степової зони. В умовах 70-79\% зімкненості крон дерев розмірна структура підстилкової мезофауни наближається до оптимальної. Відносна чисельність мурах у підстилковій мезофауні максимальна (73\%) у розріджених деревостанах (менше $49 \%$ ), відносна частка Isopoda максимальна (медіана 40\%) також в умовах розрідженого деревного намету (50-59\%). У зімкнених деревостанах таксономічна структура на рівні рядів і родин стає більш вирівняною, у ній зникають домінанти, 3 відносною чисельністю понад 15\%. Відносна чисельність більшості домінантних родин і рядів у градієнті зімкненості крон дерев достовірно не змінюється. Вплив покриття трав'яного ярусу менший, ніж деревного ярусу. Чисельність мезофауни підстилки широколистяних лісів максимальна у двох крайніх варіантах розвитку трав'яного ярусу: фрагментарний трав'яний ярус (покриття менше 15\%) та щільний травостій (покритя 90-100\%). Мінімальна чисельність підстилкової мезофауни реєструється в умовах середнього покриття трав'яними рослинами (45-59\%). Кількість видів, індекси різноманіття Шеннона та Пілоу достовірно не змінюються у градієнті покриття грунту трав'яними рослинами у широколистяних степових лісах. Кількість видів фітофагів зростає в лісових екосистемах із середніми значеннями покриття трав'янистих рослин, а сапрофагів, зоофагів і поліфагів достовірно не змінюється. Структура домінування підстилкової мезофауни найбільшою мірою трансформована у крайніх варіантах розвитку трав'яного ярусу: за фрагментарного трав'яного покриву (менше 15\%) та суцільного розвитку трав'яного ярусу (90-100\%). Медіана кількості видів турунів максимальна для 15-29\% покриття трав'яного ярусу. Відносна чисельність Сarabidae у проаналізованих градаціях покриття трав'яної рослинності достовірно не змінюється. Медіана відносної чисельності Formicidae максимальна в умовах 60 $74 \%$ покриття трав'яної рослинності, Isopoda - за 15-59\% покриття трав'яного ярусу.

Ключові слова: різноманіття; трофічна структура; розмірна структура; структура домінування; лісові екосистеми

\section{Influence of tree crown density and density of the herbaceous layer on the structure of litter macrofauna of the deciduous forests of Ukraine steppe zone}

\author{
V.V. Brygadyrenko \\ Oles Honchar Dnipropetrovsk National University, Dnipropetrovsk, Ukraine
}

The count of litter macrofauna was carried out in 339 natural deciduous forest sites in Dnipropetrovsk, Zaporizhzhya, Nikolaev and Donetsk regions of Ukraine in 2001-2014. It was shown that tree crown density did not significantly influence the abundance of litter macro-

Дніпропетровський національний університет імені Олеся Гончара, пр. Гагаріна, 72, Дніпропетровськ, 49000, Україна Oles Honchar Dnipropetrovsk National University, Gagarin Ave., 72, Dnipropetrovsk, 49010, Ukraine

Tel.: +38-050-939-07-88.E-mail: brigad@ua.fm 
fauna and the abundance of litter invertebrates. The Shannon and Pielou diversity indexes have a tendency to raise the gradient of tree crown density (from $50 \%$ to $90-100 \%$ ). The relative abundance of saprophages and zoophages reached its minimum (median was $18 \%$ and $3 \%$, respectively) in forest sites with sparse crown cover, and, at the level of tendency, was higher in dense forests with a closed crown (median was $40 \%$ and $18 \%$, respectively). The relative abundance of polyphages, on the contrary, was lower in these conditions ( $82 \%$ in sparse and $27 \%$ in closed crown cover). The number of species in each trophic group did not significantly change in relation to tree crown density. At sites with 70-79\% tree crown density the size structure of the litter macrofauna was close to its optimal condition. The relative abundance of ants reached its maximum (median 73\%) in sparsely timbered sites (up to 50\% tree crown density), the relative share of Isopoda reached its maximum (median 40\%) at sites with average crown density (50-59\%). At densely wooded sites the taxonomic structure at the level of order and family was more or less level, without clearly dominant groups, each order and family occupying about $15 \%$ of the total number of macrofauna. The relative abundance of the majority of orders and families did not significantly vary in response to different levels of tree crown density. The influence of herbaceous layer cover on macrofauna was in general less than that of tree crown density. The abundance of litter macrofauna in deciduous forests reached its maximum at sites with the two extreme variants of herbaceous layer cover: sparse herbaceous cover (up to 15\%) and dense herbaceous cover (over 90\%). The minimal abundance of litter macrofauna was observed at sites with average herbaceous layer density (45-59\%). The number of species and the Shannon and Pielou diversity indexes did not vary significantly in relation to changes in herbaceous layer density in deciduous forests of the steppe zone of Ukraine. The number of phtyophage species was higher at sites with average values for herbaceous layer density, while the number of saprophage, zoophage and polyphage species did not significantly change. The dominance structure of litter macrofauna was maximally transformed at sites with the extreme variants of herbaceous layer cover: sparse herbaceous cover (up to 15\%) and dense herbaceous cover (over 90\%). The median number of ground beetle species reached its maximum at sites with $15-29 \%$ herbaceous layer cover. The median of the relative abundance of ground beetles did not significantly change relative to the extent of herbaceous layer cover. The median of the relative abundance of Formicidae reached its maximum at sites with 60-74\% herbaceous layer cover and for Isopoda this maximum was reached at sites with 15-59\% herbaceous layer cover.

Keywords: diversity; trophic structure; dimensional structure; structure of domination; forest ecosystems

\section{Ветуп}

Стабільність умов зволоження має найбільший вплив на багатство підстилкової мезофауни в умовах лісів степової зони (Brygadyrenko, 2014). Для більшості видів мезофауни достатньо середньої зволоженості середовища, але необхідна умова - стабільність гідрологічного режиму (Jabin et al., 2004). Необхідно, щоб зволоження було постійним протягом усього теплого періоду року (Bachinsky, 1962; Belgard, 1971). Гідрологічний режим підтримується на сталому рівні за умов середньої та високої зімкненості крон деревного та чагарникового ярусів, а також покриття трав'янистих рослин (Grytsan, 2000; Ivan'ko, 2009). 3 одного боку, вегетативні органи рослин унеможливлюють надмірне перегрівання поверхні підстилки прямими сонячними променями у середині дня, 3 іншого - через продихи рослин під лісовий намет надходить додаткова волога, піднята корінням із глибини понад один метр.

Тіньова світлова структура насаджень забезпечує створення лісового мікроклімату, сприятливого для існування грибів і бактерій, здатних формувати специфічні сполуки у складі підстилки (Belgard, 1971; Grytsan, 2000), які збагачують опале листя на певних етапах ферментації речовинами, придатними до споживання сапрофагами. Отже, вплив світла на мезофауну може відбуватися не тільки безпосередньо, а й опосередковано.

Розвиток трав'янистих рослин триває протягом сезону нерівномірно. Весняні лісові ефемери та ефемероїди можуть утворювати щільний покрив (Asarum europaeum L., Polygonatum multiflorum (L.) All., Pulmonaria obscura Dumort., Viola odorata L., V. hirta L., Convallaria majalis L. тощо), натомість на початку літа кількість вегетуючих видів та їх сумарне покриття істотно зменшується (домінують Aegopodium podagraria L., Anthriscus sylvestris (L.) Hoffm., Stellaria holostea L., Glechoma hederacea L., Ballota nigra L.) через ущільнення листяного намету чагарників і дерев, а також зменшення кількості атмосферних опадів, які здатні досягати поверхні грунту в середині сезону вегетації. Наприкінці літа підстилка та верхні горизонту грунту у більшості типів степових лісів висихають, що унеможливлює підтримання активності для значної частини видів безхребетних: тварини переходять у стан діапаузи. Восени у травя'ному покриві внаслідок поступового опадання листя чагарників і дерев оптимізується освітленість, зростає кількість опадів, що забезпечує можливість вегетації частини видів (у першу чергу Chelidonium majus L., Galium aparine L. та Stellaria media (L.) Vill.). Отже, керівною підсистемою лісу виступають деревний і чагарниковий яруси, підпорядкованою - трав'янисті рослини. Підстилкові безхребетні тварини змінюють свою чисельність (розмноження або загибель, горизонтальна або вертикальна міграція) у мінливих умовах рослинного покриву, який, у свою чергу, формується під впливом атмосферних опадів, за певних грунтово-рослинних умов.

Комплексних досліджень, присвячених аналізу основних характеристик підстилкової мезофауни та виконаних на значній кількості пробних ділянок, досі проведено не достатньо (Stamps and Linit, 1997; Reynolds et al., 2003; Sobek et al., 2009). Спостереження для декількох десятків пробних ділянок (Brygadyrenko, 2003, 2004; Brygadyrenko and Solovjov, 2007; Brygadyrenko and Komarov, 2008; Fedorchenko and Brygadyrenko, 2008; Moroz et al., 2011; Brygadyrenko et al., 2012; Faly and Brygadyrenko, 2014) не дозволяють установити загальні закономірності мінливості підстилкової мезофауни. Тому мета даної статті - оцінити загальні закономірності мінливості основних характеристик, трофічної, розмірної, таксономічної структури та структури домінування угруповань підстилкової мезофауни у природних широколистяних лісах степової зони України у градієнті зімкненості крон дерев і покриття трав'янистих рослин.

\section{Матеріал і методи досліджень}

Обстежено пробні ділянки лісових екосистем на території Дніпропетровської, Запорізької, Миколаївської, Донецької областей України, ліси 30-200-річного віку (2001-2014 рр.). Під час геоботанічного опису за станда- 
ртною методикою враховували ступінь зімкненості деревного та чагарникового ярусів, покриття трав'яного біогеогоризонту для всіх рослин (для кожного виду окремо та для всіх видів певного ярусу разом). Проаналізовано 339 лісових екосистем, детальну характеристику яких наведено у попередній публікації (Brygadyrenko, 2015).

Грунтові пастки (500 мл із $20 \%$ розчином $\mathrm{NaCl}$ ) перевіряли залежно від погодних умов кожні 5-7 діб протягом 20-185 діб (від 3 до 24 вибірок на кожній пробній ділянці). Для порівняння структури угруповань мезофауни підстилки аналізували 20-добові проміжки часу (середина червня) по одному для кожної пробної ділянки. Різноманіття мезофауни (Shannon and Weaver, 1949; Pilou, 1977) та інші проаналізовані у статті характеристики розраховували для 20-добового періоду середини червня. Домінантами вважали родини або ряди, які перевищували 3\% сумарної чисельності мезофауни. Обробку результатів здійснювали у пакеті програм Statistica 8.0. На діаграмах показані медіана, 25-75\% квартилі та окремі точки даних: так звані «викиди» $\left(^{\circ}\right)$ та «екстремуми» (*). У тексті наведено лише медіани характеристик: саме вони, а не середні значення найпоказовіші для розподілу, який часто відхиляється від нормального. Для порівняння вибірок застосовано однофакторний дисперсійний аналіз, при цьому розбіжності між значеннями характеристик вважали достовірними за $\mathrm{P}<0,05$.

\section{Результати та їх обговорення}

\section{Вплив на підстилкову мезофауну зімкненості крон деревного ярусу}

Основні характеристики. Зімкненість крон дерев достовірно не впливає на чисельність підстилкової мезофауни та кількість видів безхребетних у підстилці (рис. 1). Індекси різноманіття Шеннона та Пілоу мають тенденцію до підвищення у градієнті зімкненості крон дерев (від менше 50\% до 90-100\%), їх медіана зростає 3 1,5 до 3,5 та з 0,34 до 0,82 біт відповідно (рис. 16, г).

трофічна структура. Відносна чисельність фітофагів (рис. $2 a$ ) має тенденцію до зростання з $0,5 \%$ у розріджених деревостанах (зімкненість менше 50\%) до $5 \%$ у лісах із зімкненим наметом (90-100\%). Відносна чисельність сапрофагів і зоофагів мінімальна (медіана $18 \%$ та $3 \%$ ) у лісових екосистемах із розрідженим наметом (рис. 2б, в), має тенденцію до зростання у лісах із зімкненим деревостаном (40\% та 18\%). Відносна чисельність поліфагів у мезофауні, навпаки, за цих умов зменшується $382 \%$ до $27 \%$ (рис. 22). Кількість видів кожної із чотирьох розглянутих трофічних груп достовірно не змінюється у градієнті зімкненості крон дерев у широколистяних лісах степової зони (рис. 3).

Структура домінування. Кількість рідкісних видів (менше 1,5\% за чисельністю) максимальна за умов зімкненості крон 70-79\% (рис. 42), мінімальна - за 90100\% зімкненості (рис. 4е). Мінімальна кількість домінантних видів спостерігається за умов 80-89\% зімкненості крон (рис. 4d). У крайніх варіантах (за умов розрідженого намету із зімкненістю менше 50\% та ущільненого деревостану із зімкненістю понад 90\%) дослідженого градієнта спостерігається трансформація структури домінування угруповання підстилкової мезофауни (рис. $4 a, e$ ). Оптимальна структура домінування зареєстрована за умов зімкненості крон 70-79\% (рис. 42).

Розмірна структура. Частка найменшої розмірної групи (менше 4 мм довжини тіла) максимальна у розріджених широколистяних лісах (медіана $73 \%$, рис. $5 a$ ). Висота основного піка для розмірної групи 4-7 мм максимальна $(69 \%$, рис. 5б) у широколистяних лісах із 50 59\% зімкненості крон, поступово зменшуючись до 19$28 \%$ за умов 80-100\% зімкненості крон (рис. $5 \partial, e)$. Частка максимальних за розмірами тіла безхребетних (понад 20 мм) достовірно не змінюється у градієнті зімкненості крон дерев. Додаткові піки для розмірної групи 12-15 мм довжини тіла наявні у варіантах із розрідженими кронами дерев (до 50\% та 50-59\%, рис 5a, б). За умов 70-79\% зімкненості крон дерев (рис. 52) розмірна структура підстилкової мезофауни наближається до оптимальної.

Подібні закономірності прослідковуються і за розмірною структурою підстилкової мезофауни за кількістю видів (рис. 6). Кількість видів мінімальної за розмірами групи мезофауни (менше 4 мм) достовірно не змінюється у градієнті зімкненості крон. Висота піка для групи 4-7 мм максимальна (11 видів) за умов 50-59\% зімкненості крон (рис. 6б). В усіх градаціях наявні 12 види безхребетних (медіана), довжиною тіла понад 20 мм. Як і за чисельністю, за кількістю видів у розмірній структурі лісових екосистем із розрідженим наметом (менше 50\%) також спостерігається додатковий пік для розмірної групи довжиною тіла 12-15 мм (рис. 6а).

Таксономічна структура. При зростанні зімкненості крон дерев кількість видів домінантних родин і рядів безхребетних у підстилковій мезофауні достовірно не змінюється (рис. 7). Кількість видів мурах досягає максимуму (медіана -4 види) в умовах розрідженого деревного намету (50-59\%, рис. 7б). Відносна чисельність мурах у підстилковій мезофауні максимальна (73\%) також у розріджених деревостанах (менше 49\%, рис. 8a), відносна частка Isopoda максимальна (медіана 40\%) також за умов розрідженого деревного намету (50-59\%, рис. 8б). За умов зімкнених деревостанів таксономічна структура на рівні рядів і родин стає більш вирівняною, у ній зникають домінанти, з відносною чисельністю понад $15 \%$ (рис. $8 \partial$, e). Відносна чисельність більшості домінантних родин і рядів у градієнті зімкненості крон дерев достовірно не змінюється.

Вплив на підстилкову мезофауну покриття трав'яного ярусу

Основні характеристики. Сумарна чисельність мезофауни підстилки широколистяних лісів максимальна за умов двох крайніх варіантів розвитку трав'яного ярусу: фрагментарний трав'яний ярус (зімкненість менше $15 \%)$ - 103 екз./100 пастко-діб та щільний травостій (зімкненість 90-100\%) - 141 екз./100 пастко-діб (рис. 9a). Мінімальна чисельність підстилкової мезофауни (медіана - 16 екз./100 пастко-діб) реєструється за умов середнього покриття трав'яними рослинами (45-59\%, рис. $9 a)$. Кількість видів, індекси різноманіття Шеннона та Пілоу (рис. 9б, в, г) достовірно не змінюються у градієнті покриття грунту трав'яними рослинами у широколистяних степових лісах.

Трофічна структура. Відносна чисельність фітофагів (рис. 10a) у підстилковій мезофауні має тенденцію до 
зменшення з 4-6\% у широколистяних лісах із фрагментарним трав'яним ярусом (менше $45 \%$ ) до $1 \%$ у лісах із щільним трав'яним покривом (понад 75\%). Відносна чисельність сапрофагів, зоофагів і поліфагів (рис. 10б, в, г) достовірно не змінюється залежно від проективного по- криття трав'янистих рослин у широколистяних лісах степової зони. Кількість видів фітофагів зростає в лісових екосистемах із середніми значеннями покриття трав'янистих рослин (рис. 11a), а сапрофагів, зоофагів і поліфагів достовірно не змінюється (рис. 116, в, г).
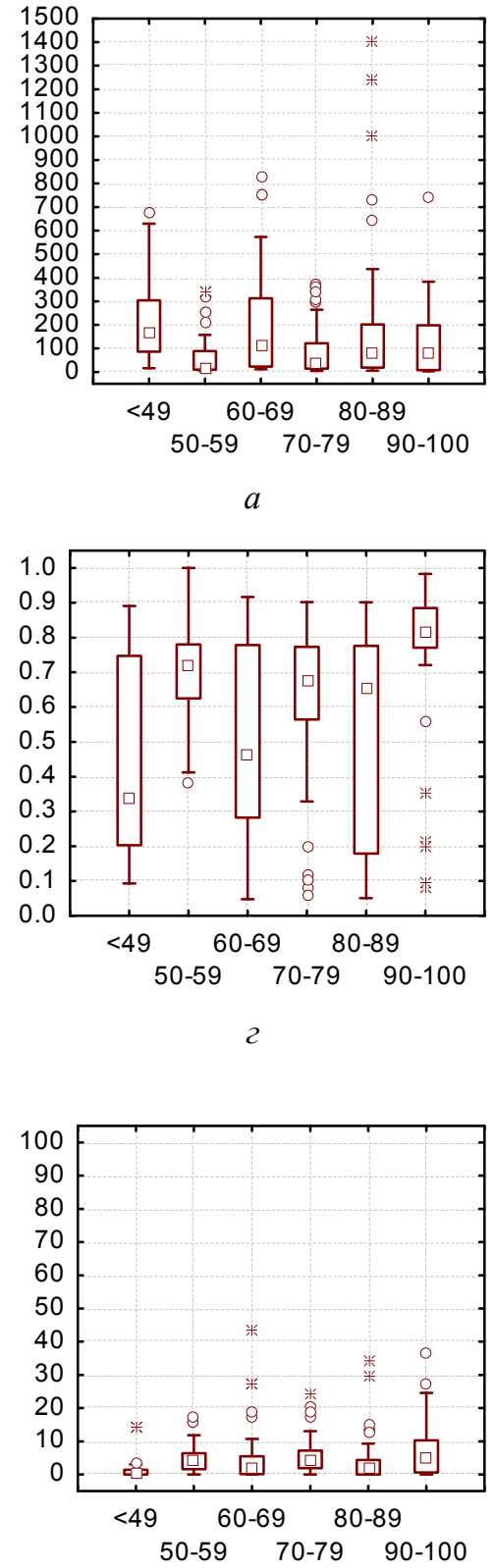

$a$

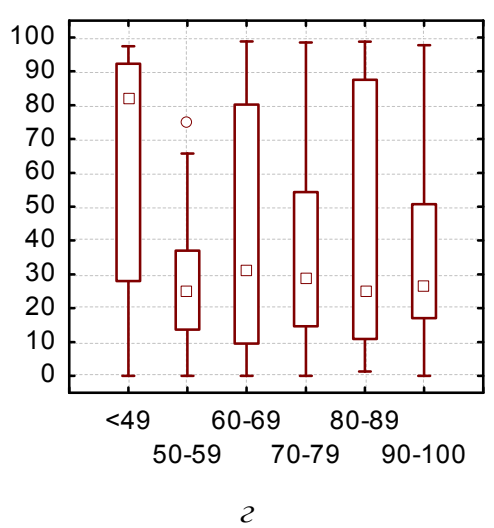

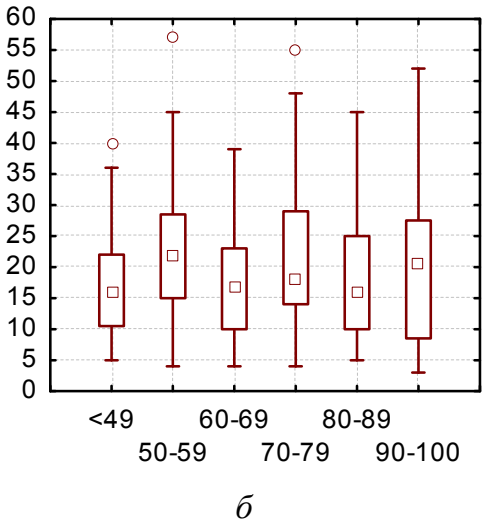

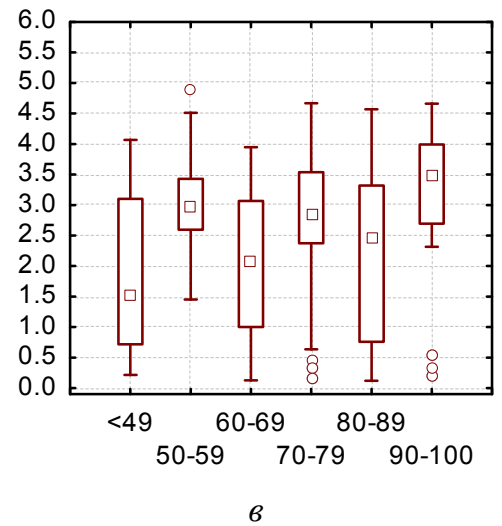

Рис. 1. Основні характеристики підстилкової мезофауни широколистяних лісів степової зони залежно від зімкненості крон деревного ярусу:

$a$ - сумарна чисельність (екз./100 пастко-діб), $\sigma$ - кількість видів, в - індекс Шеннона (біт), г - індекс Пілоу (біт); по осі абсцис зімкненість крон деревного ярусу, по осі ординат значення характеристик

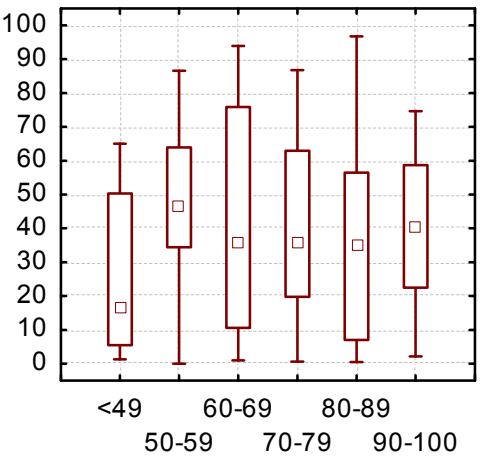

$\sigma$

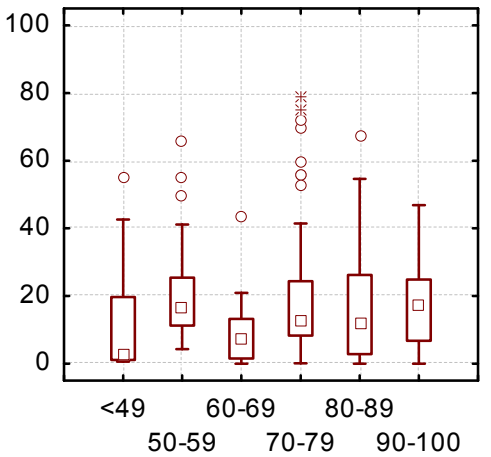

B
Рис. 2. Трофічна структура (за чисельністю) підстилкової мезофауни широколистяних лісів степової зони залежно від зімкненості крон деревного ярусу: $a$ - фітофаги, $\sigma$ - сапрофаги, $b$ - зоофаги, 2- поліфаги; по осі абсцис - зімкненість крон деревного ярусу, по осі ординат - частка трофічної групи в герпетобії (\%) 


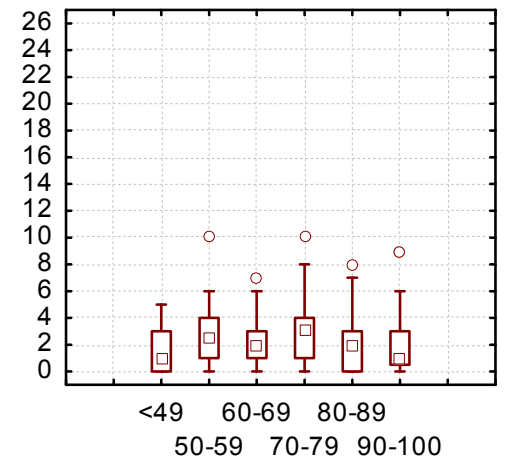

$a$

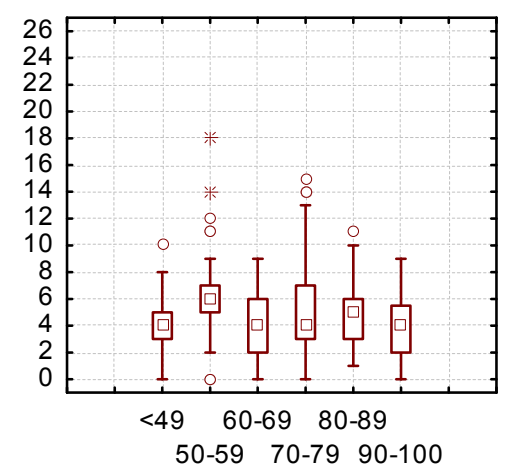

2

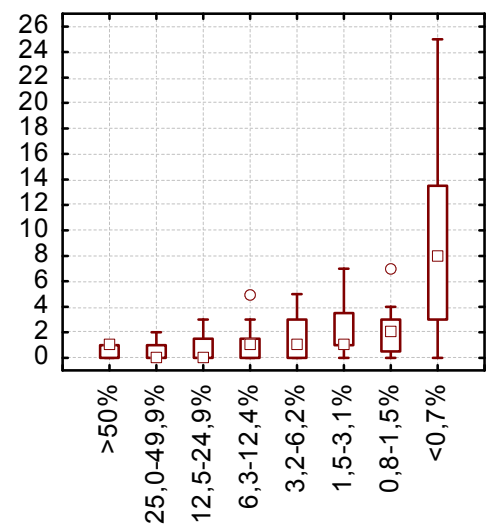

$a$

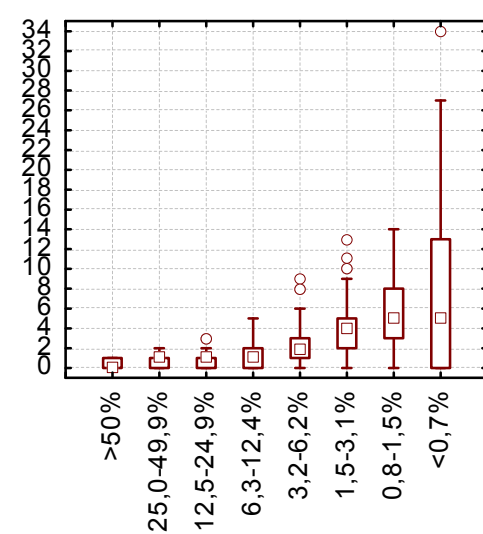

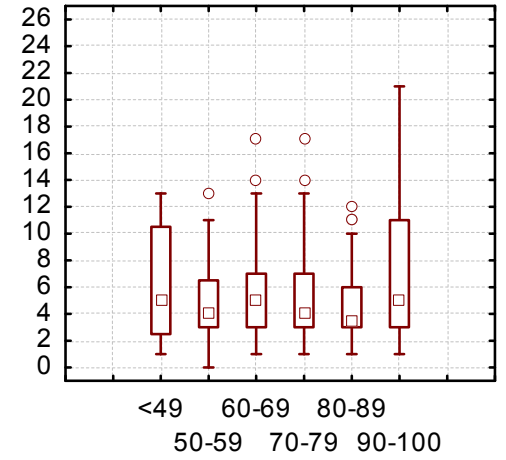

$\sigma$

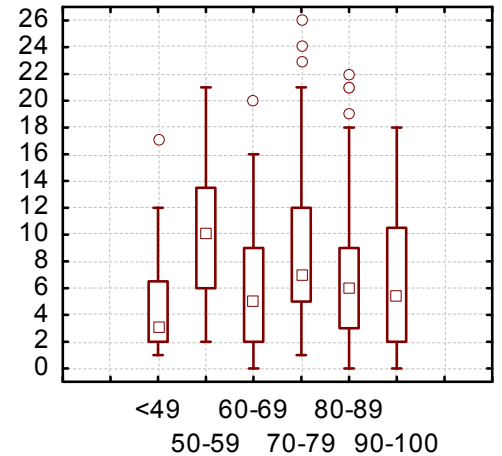

B

Рис. 3. Трофічна структура (за кількістю видів) підстилкової мезофауни широколистяних лісів степової зони залежно від зімкненості крон деревного ярусу: $a$ - фітофаги, $\sigma$ - сапрофаги, $b$ - зоофаги, 2 - поліфаги; по осі абсцис - зімкненість крон деревного ярусу, по осі ординат - кількість видів в угрупованні

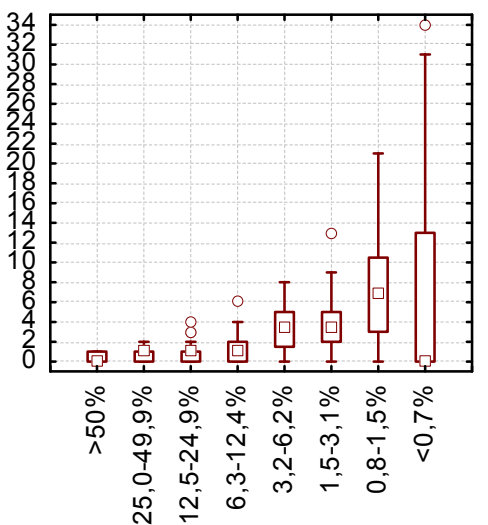

6

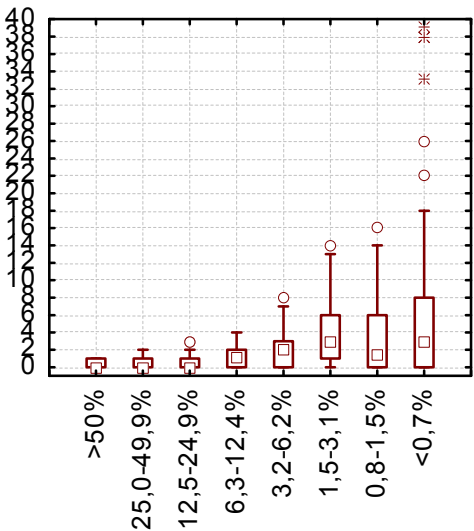

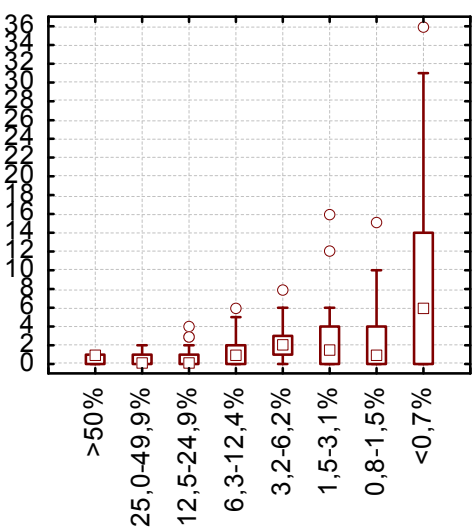

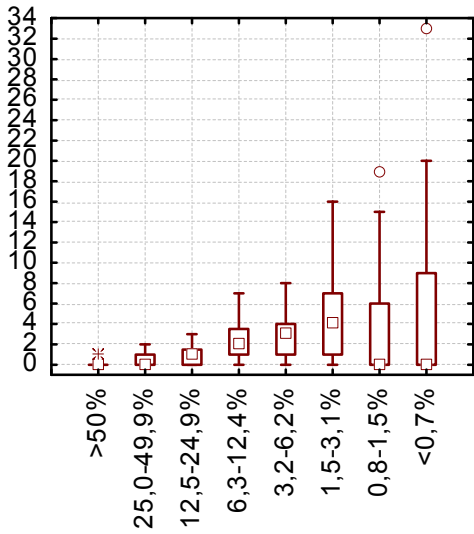

$e$

Рис. 4. Структура домінування підстилкової мезофауни широколистяних лісів степової зони залежно від зімкненості крон деревного ярусу: $a-$ зімкненість крон дерев $<49 \%, \sigma-50-59 \%, 6-60-69 \%, 2-70-79 \%, \partial-80-89 \%$, $e-90-100 \%$; по осі абсцис - частка виду в угрупованні (\%), по осі ординат - кількість видів в угрупованні 


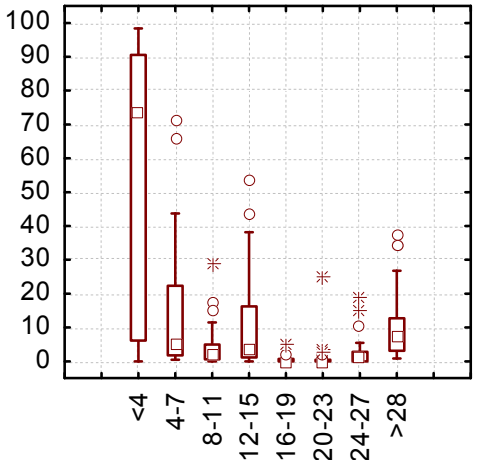

$a$

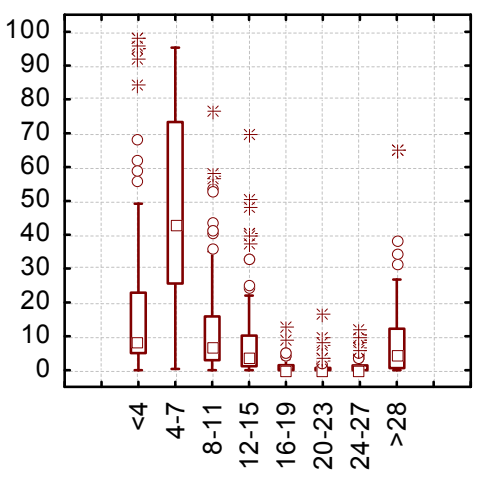

2

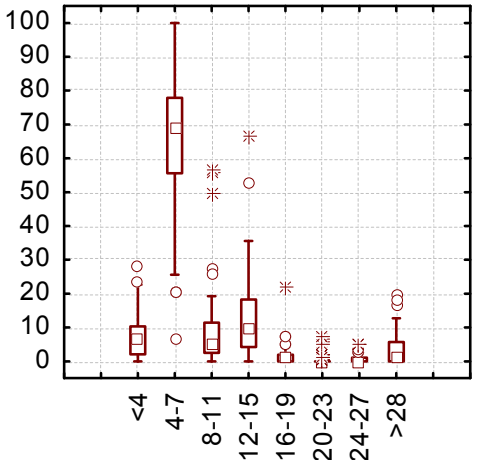

$\sigma$

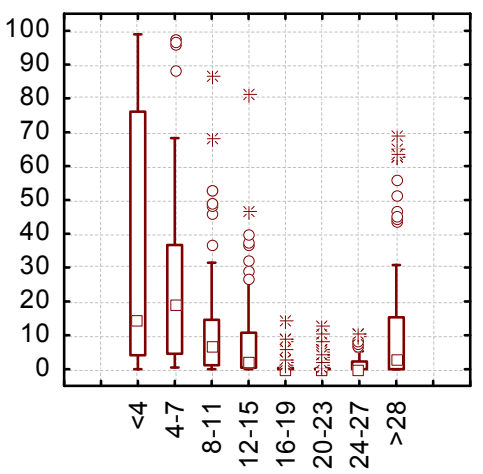

$\partial$

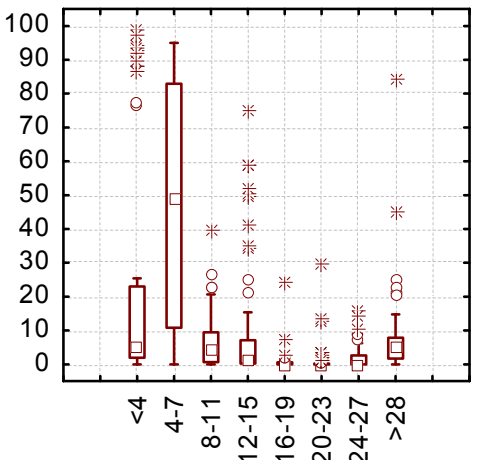

B

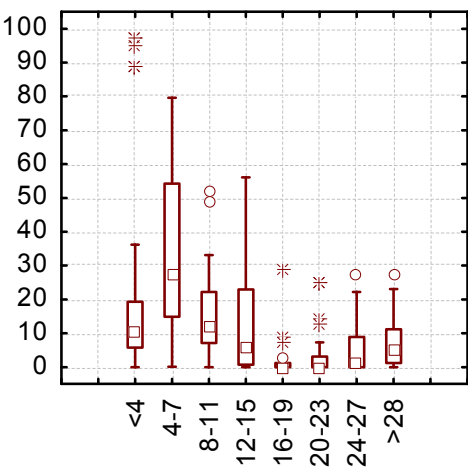

e

Рис. 5. Розмірна структура підстилкової мезофауни широколистяних лісів степової зони залежно від зімкненості крон деревного ярусу: а - зімкненість крон дерев < 49\%, б - 50-59\%, в - 60-69\%, г - 70-79\%, д - 80-89\%, е - 90-100\%; по осі абсцис - довжина тіла особин (мм), по осі ординат - частка особин даної розмірної групи за чисельністю (\%)
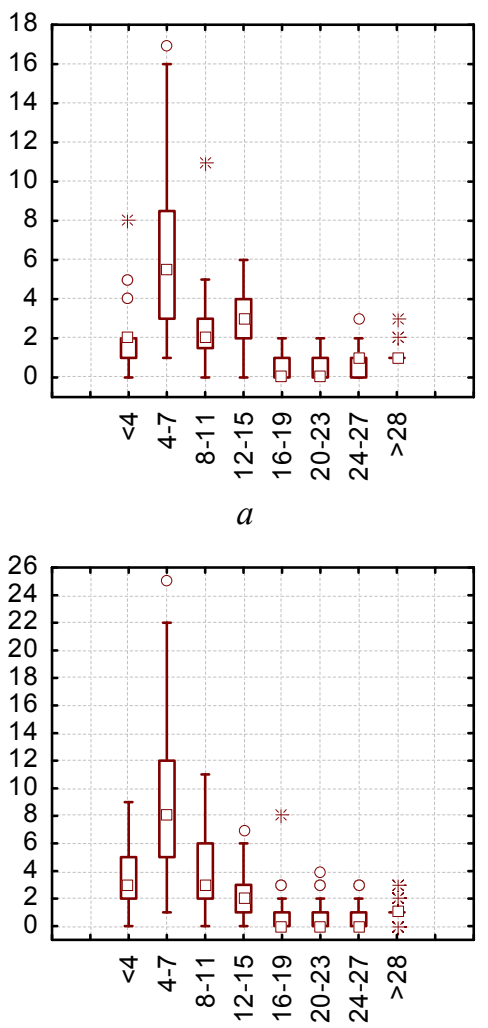

2

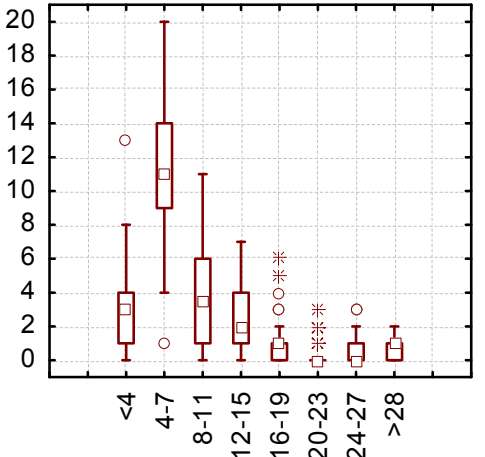

$\sigma$

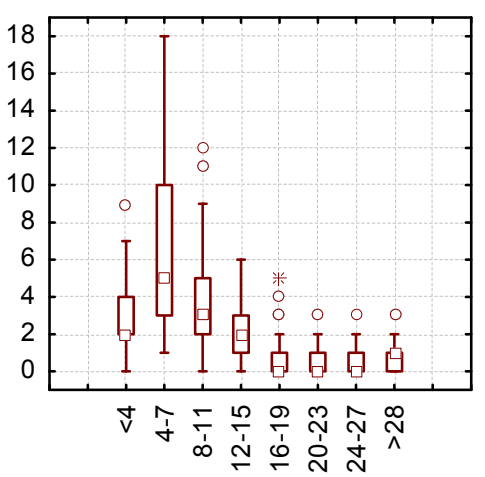

$\partial$

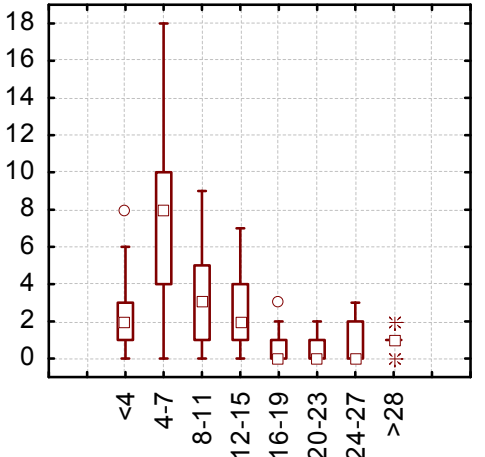

B

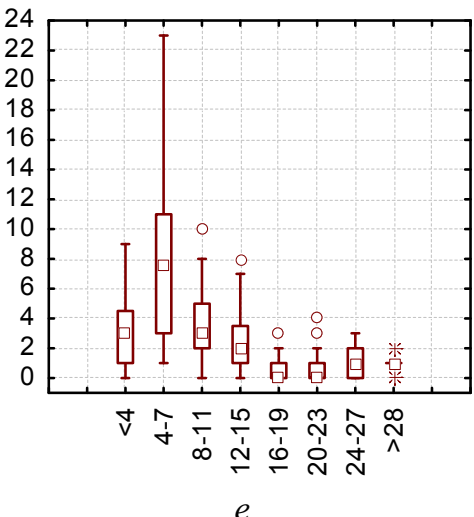

Рис. 6. Розмірна структура підстилкової мезофауни широколистяних лісів степової зони залежно від зімкненості крон деревного ярусу: $a-$ зімкненість крон дерев $<49 \%, 6-50-59 \%, \varepsilon-60-69 \%, 2-70-79 \%, \partial-80-89 \%, e-90-100 \%$; по осі абсцис - довжина тіла особин (мм), по осі ординат - кількість видів даної розмірної групи 


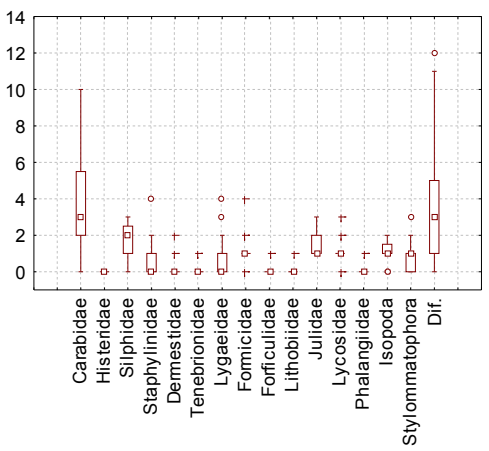

$a$

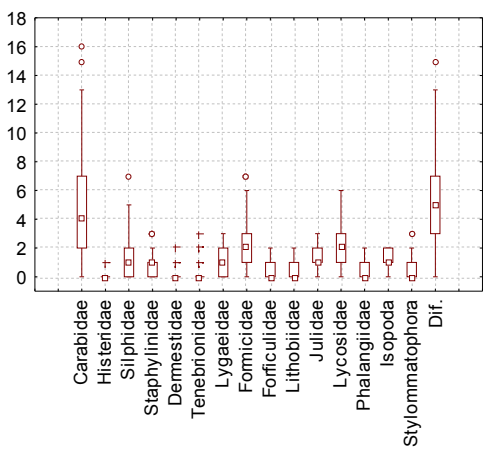

2

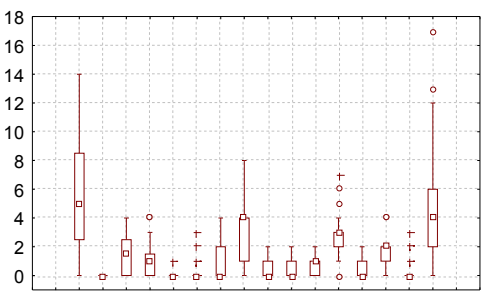

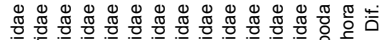

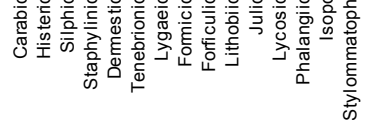

$\sigma$

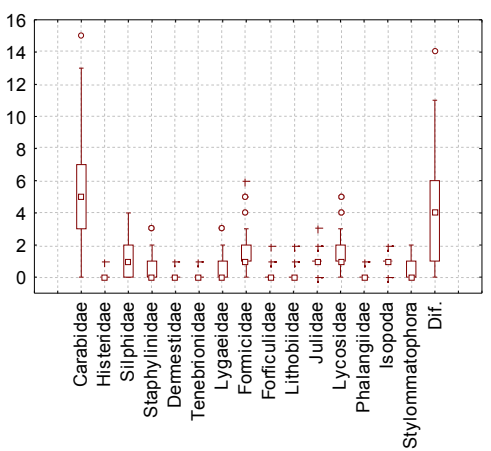

$\partial$

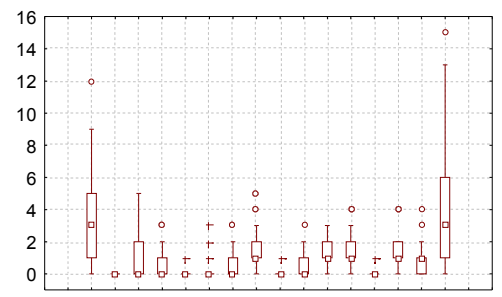

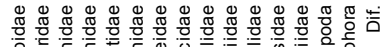

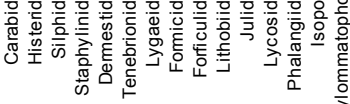

$B$

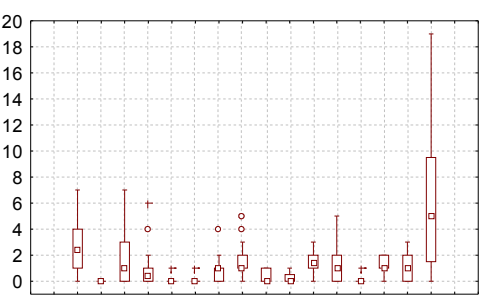

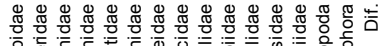

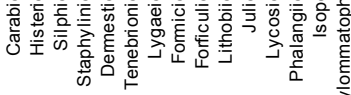

Рис. 7. Таксономічна структура підстилкової мезофауни широколистяних лісів степової зони залежно від зімкненості крон деревного ярусу: $a$ - зімкненість крон дерев $<49 \%, \sigma-50-59 \%$, в-60-69\%, $2-70-79 \%, \partial-80-89 \%, e-90-100 \%$; по осі абсцис - домінантні таксономічні групи, по осі ординат - кількість видів даної групи в угрупованні; Dif. - види інших таксономічних груп

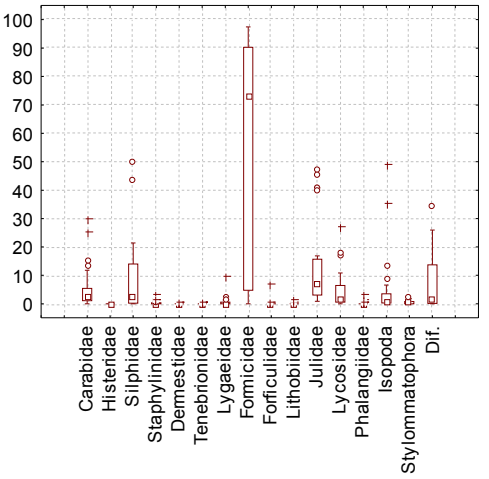

$a$

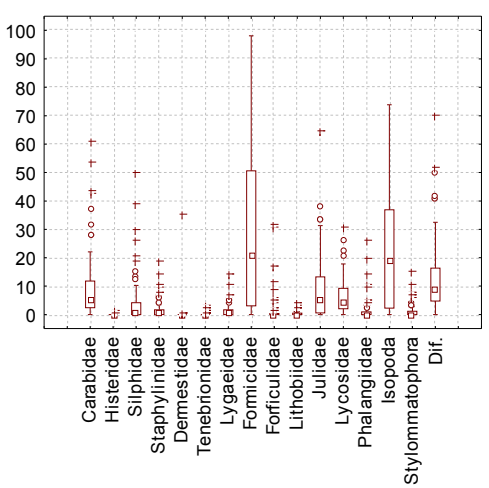

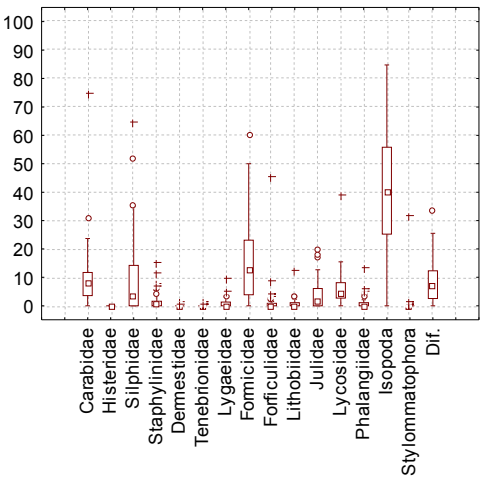

$\sigma$

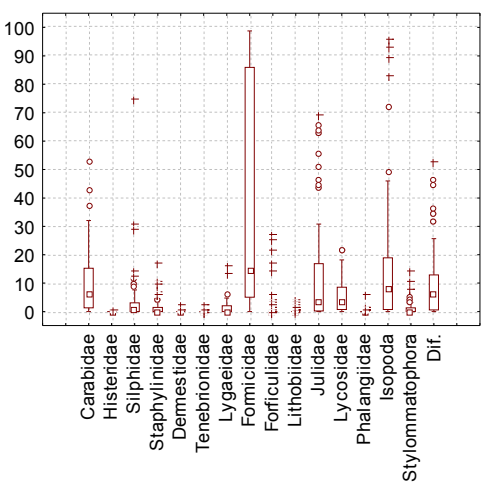

$\partial$
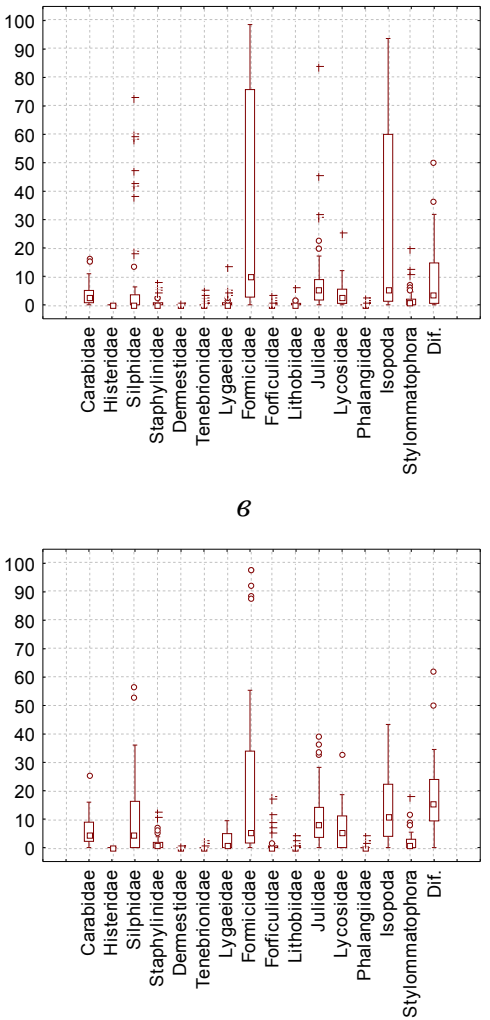

Рис. 8. Таксономічна структура підстилкової мезофауни широколистяних лісів степової зони залежно від зімкненості крон деревного ярусу: $a$ - зімкненість крон дерев $<49 \%, \sigma-50-59 \%, 6-60-69 \%, 2-70-79 \%$, $\partial-80-89 \%, e-90-100 \%$; по осі абсцис - домінантні таксономічні групи, по осі ординат - частка даної групи в угрупованні за чисельністю (\%); Dif. - види інших таксономічних груп 

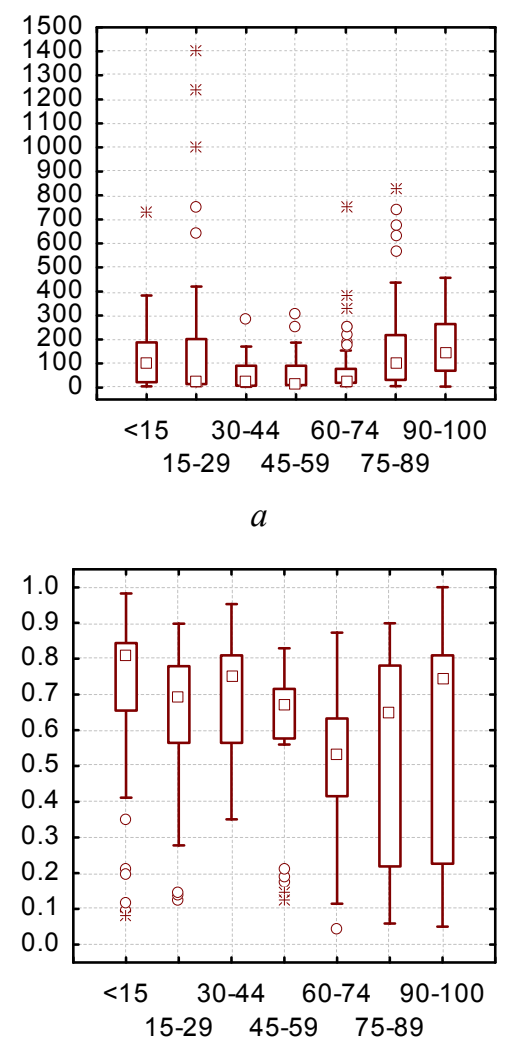

2
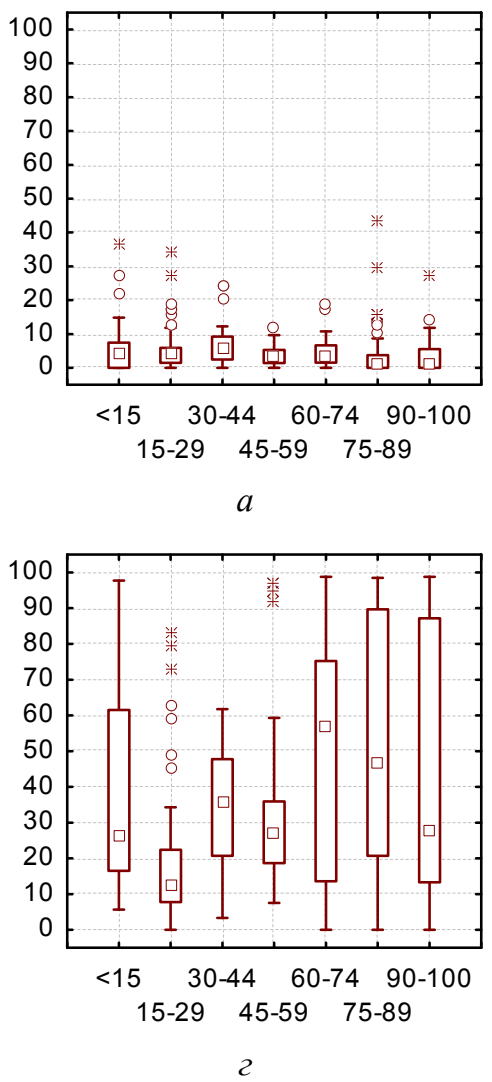

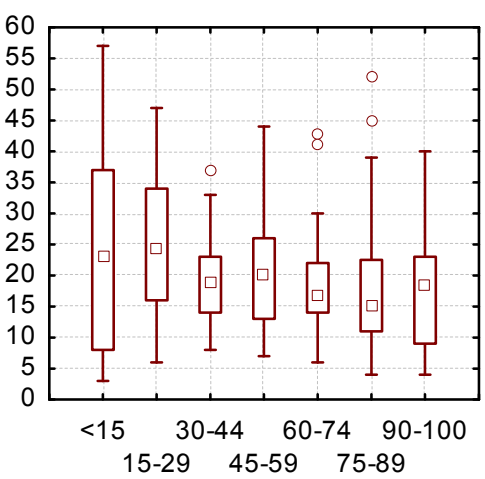

$\sigma$

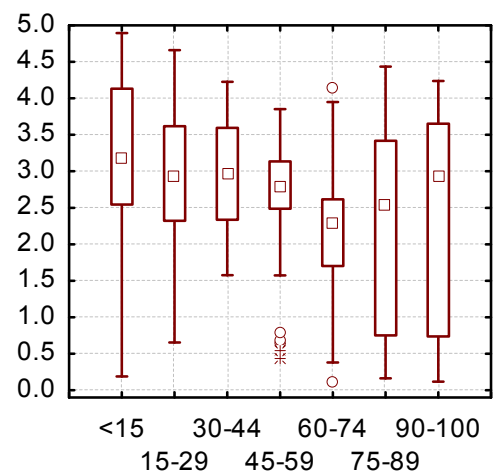

Рис. 9. Основні характеристики підстилкової мезофауни широколистяних лісів степової зони залежно від сумарного покриття трав'яного ярусу: $a$ - сумарна чисельність (екз./100 пастко-діб), $\sigma$ - кількість видів, 8 - індекс Шеннона (біт), г - індекс Пілоу (біт); по осі абсцис - сумарне покриття трав'яного ярусу, по осі ординат - значення характеристик
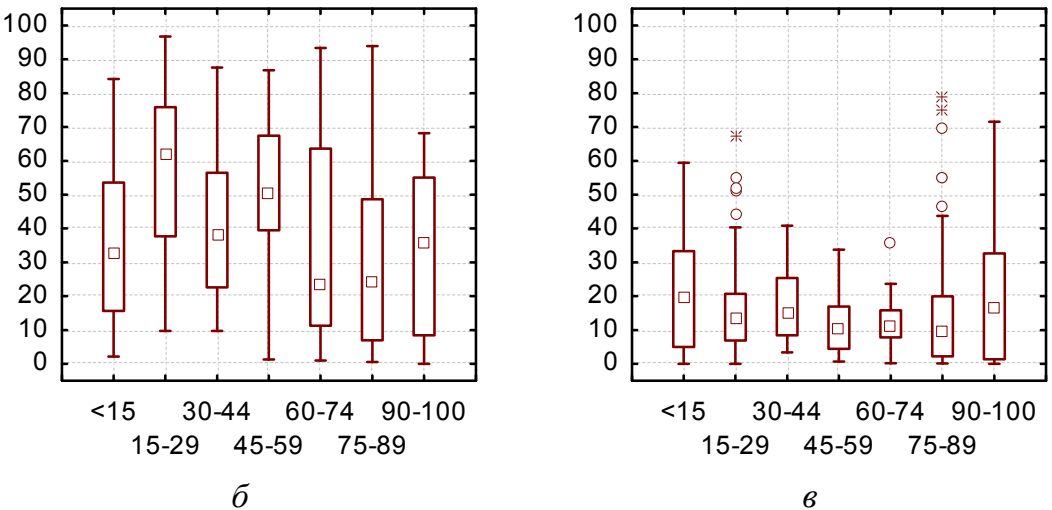

Рис. 10. Трофічна структура (за чисельністю) підстилкової мезофауни широколистяних лісів степової зони залежно від сумарного покриття трав'яного ярусу: $a$ - фітофаги, $\sigma$ - сапрофаги, $в$ - зоофаги, 2 - поліфаги; по осі абсцис - сумарне покриття трав'яного ярусу, по осі ординат - частка трофічної групи в герпетобії (\%)

Структура домінування. Частка рідкісних видів (менше 1,5\% за чисельністю) достовірно не змінюється у досліджених градаціях покриття трав'янистими рослинами (рис. 12). Структура домінування підстилкової мезофауни найбільшою мірою трансформована у крайніх варіантах розвитку трав'яного ярусу (рис. 12a, ж): за фрагментарного трав'яного покриву (менше 15\%) та суцільного розвитку трав'яного ярусу (90-100\%). 


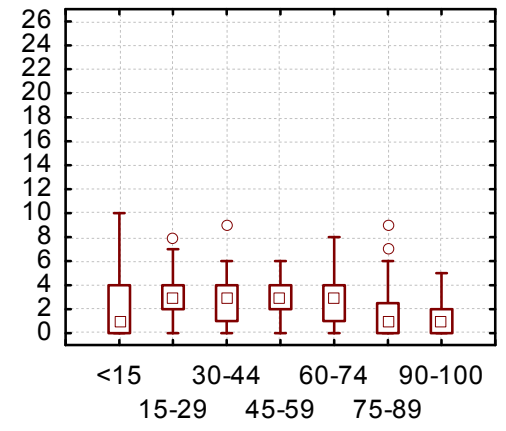

$a$

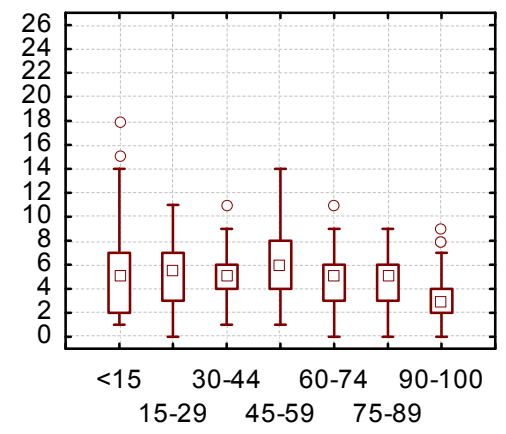

2

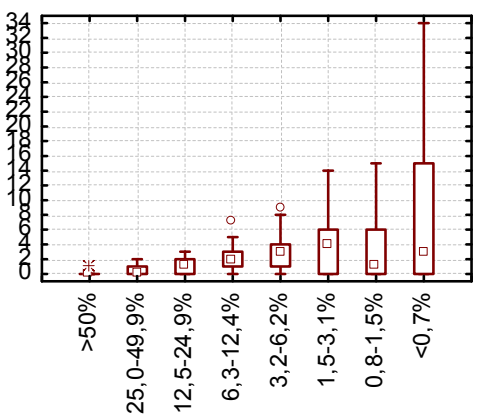

$a$

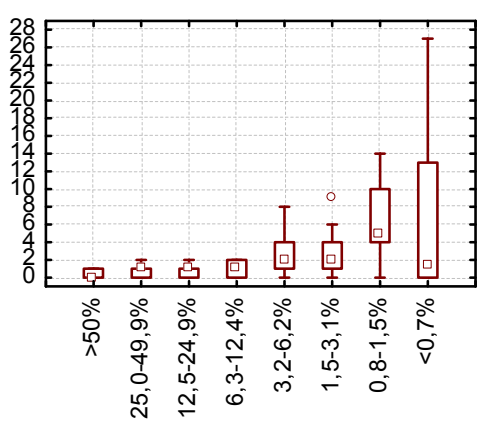

2

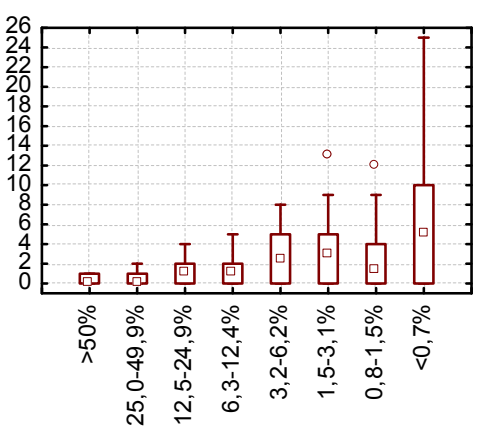

$\oiiint$

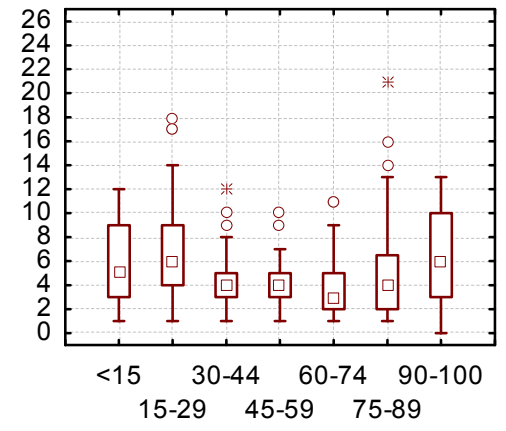

6

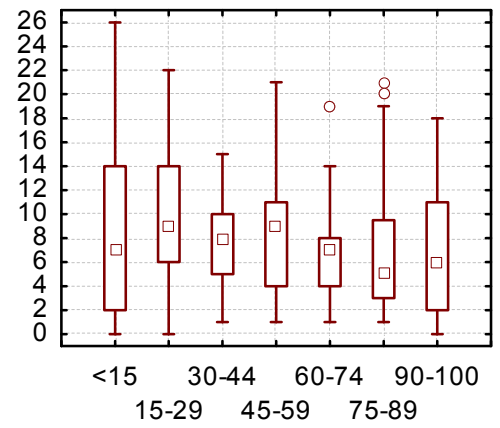

8

Рис. 11. Трофічна структура (за кількістю видів) підстилкової мезофауни широколистяних лісів степової зони залежно від сумарного покриття трав'яного ярусу: $a$ - фітофаги, $\sigma$ - сапрофаги,, - зоофаги, 2 - поліфаги; по осі абсцис - сумарне покриття трав'яного ярусу, по осі ординат - кількість видів в угрупованні

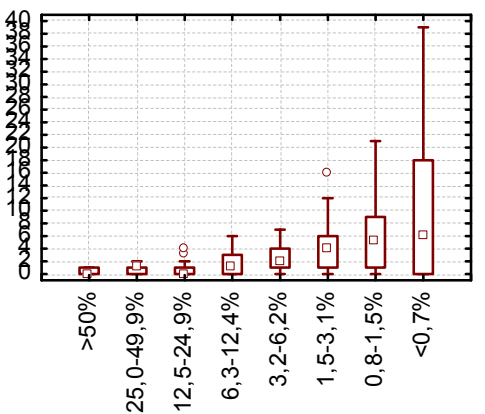

$\sigma$

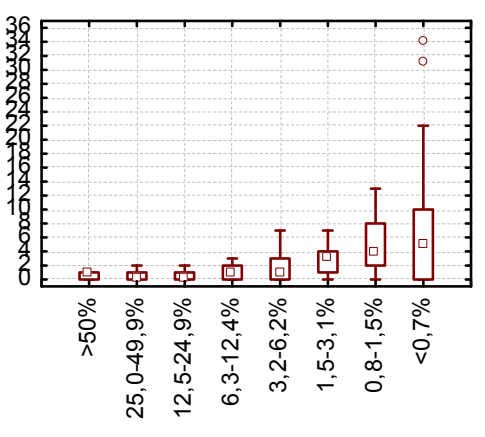

$\partial$

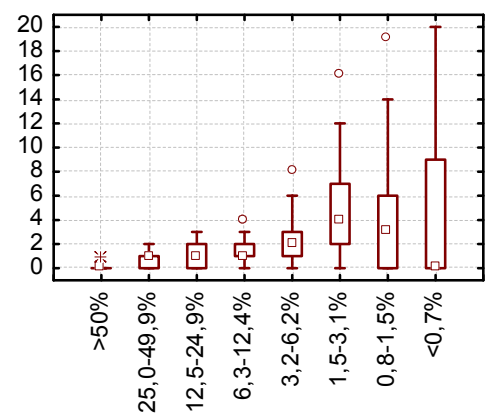

B

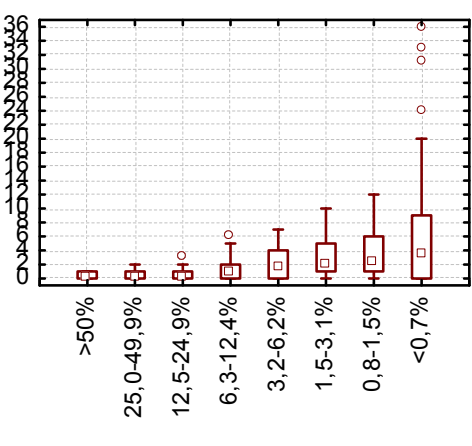

Рис. 12. Структура домінування підстилкової мезофауни широколистяних лісів степової зони залежно від сумарного покриття трав'яного ярусу: $a$ - сумарне покриття трав'яного ярусу $<15 \%, \sigma-15-29 \%$, , $-30-44 \%$, 2-45-59\%, $\partial-60-74 \%, e-75-89 \%, ж-90-100 \%$; по осі абсцис - частка виду в угрупованні (\%), по осі ординат - кількість видів в угрупованні 
Розмірна структура. Частка найменшої розмірної групи (менше 4 мм) достовірно не змінюється у градієнті покриття трав'яних рослин, досягаючи максимуму в умовах 75-89\% покриття трав'яної рослинності (рис. 13e). Медіана найчисельнішої розмірної групи (4-7 мм) достовірно зменшується з $37-74 \%$ в умовах 0-74\% покриття трав'яної рослинності до 10-23\% в умовах 75$100 \%$ покриття трав'яного ярусу (рис. 13). Найбільші розмірні групи достовірно не змінюють своєї відносної чисельності у широколистяних лісах із різним покриттям трав'яних рослин. Максимальна висота піка розмірної групи 4-7 мм за кількістю видів (8-10 видів) спостерігається у лісах із середнім (15-74\%) покриттям трав'яного ярусу (рис. 146, в, 2, $)$ ), у той час як у крайніх варіантах (фрагментарної або надзвичайно щільної трав'яної рослинності, рис. $14 a, e, ж)$ медіана для цієї розмірної групи зменшується до 6-7 видів.

Таксономічна структура. У градієнті покриття трав'яної рослинності достовірних змін кількості видів для наймасовіших родин і рядів безхребетних підстилки не зареєстровано (рис. 15). Медіана кількості видів турунів максимальна для 15-29\% зімкненості трав'яного ярусу (рис. 15б). Відносна чисельність Carabidae у проаналізованих градаціях покриття трав'яної рослинності достовірно не змінюється (рис. 16). Медіана відносної чисельності Formicidae максимальна (51\%, рис. $16 \partial)$ за умов 60-74\% покриття трав'яної рослинності; за умов зменшення чи збільшення покриття відносна чисельність мурах має тенденцію до зниження (медіана 4-25\% та 8$30 \%$ відповідно). Медіана чисельності Isopoda максимальна $(21-38 \%$, рис. 166, в, г) за умов $15-59 \%$ покриття трав'яного ярусу; у лісових екосистемах із щільнішим травостоєм відносна чисельність Isopoda зменшується до 3-7\% (рис. 16д, е, ж). Чисельність інших таксономічних груп достовірно не змінюється.

Таким чином у природних широколистяних лісах степової зони України основні характеристики підстилкової мезофауни залишаються досить стабільними, за умов зміни характеристик середовища відбувається поступова ротація видів усередині таксономічних (родин і рядів), трофічних або розмірних групп безхребетних тварин (Brygadyrenko, 2006, 2014, 2015a, 2015b).

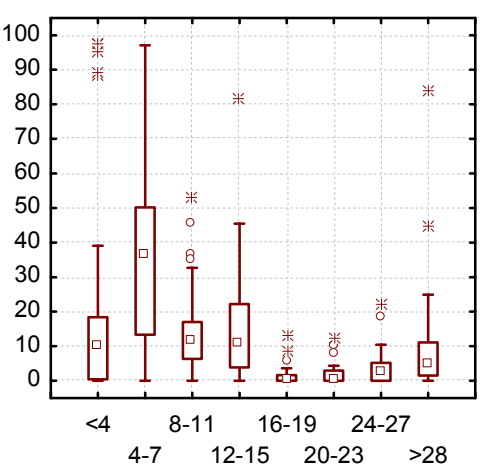

$a$

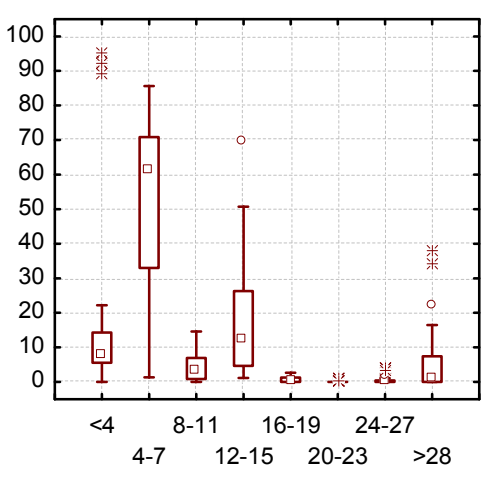

2

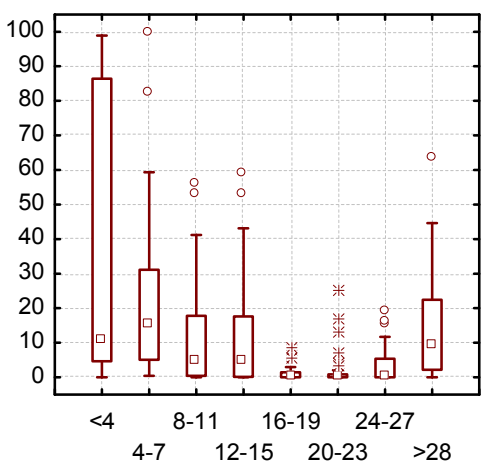

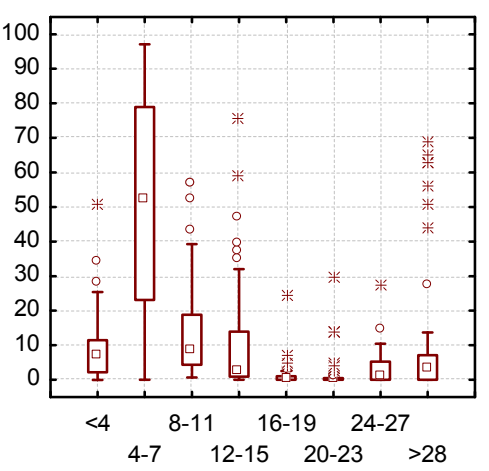

б

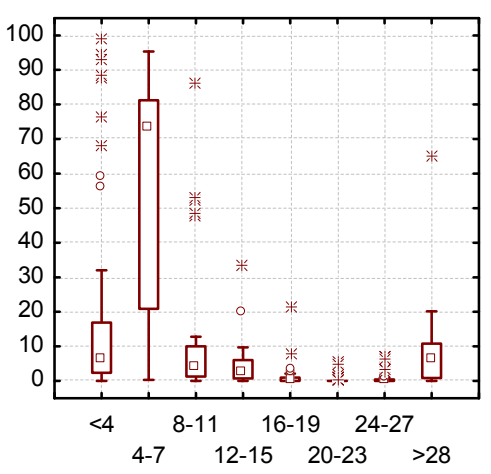

$\partial$

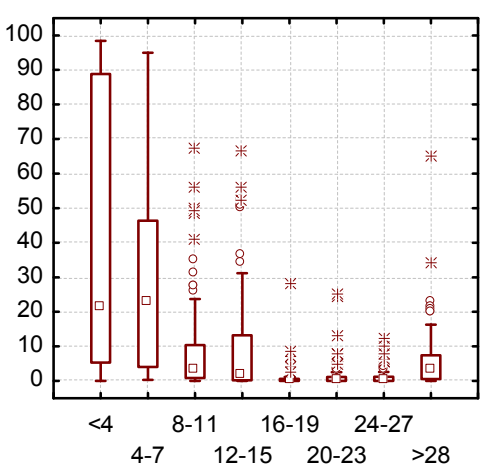

$e$

Рис. 13. Розмірна структура підстилкової мезофауни широколистяних лісів степової зони залежно від сумарного покриття трав'яного ярусу: $a$ - сумарне покриття трав'яного ярусу $<15 \%, \sigma-15-29 \%$, , $-30-44 \%$, $2-45-59 \%, \partial-60-74 \%, e-75-89 \%, ж-90-100 \%$; по осі абсцис довжина тіла особин (мм), по осі ординат - частка особин даної розмірної групи в угрупованні (\%)

Ж 


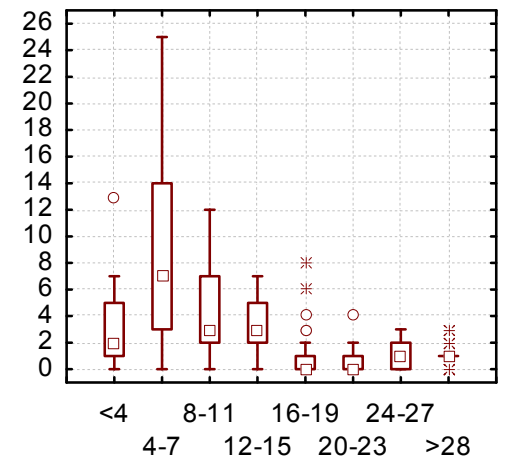

$a$

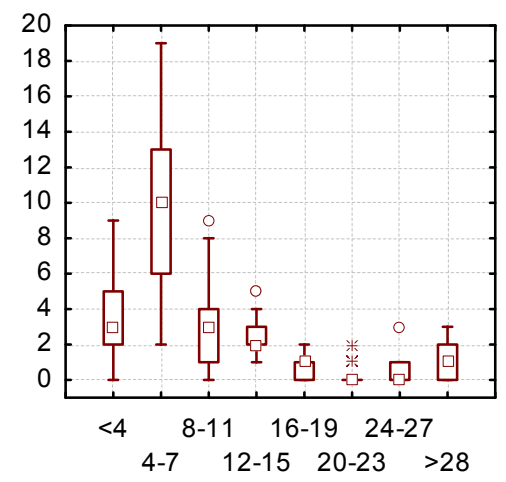

2

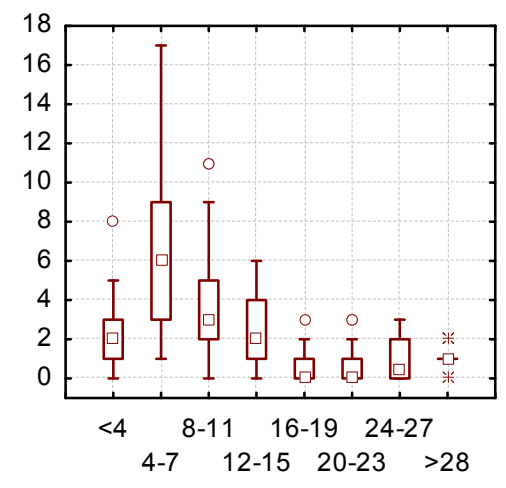

ЖC

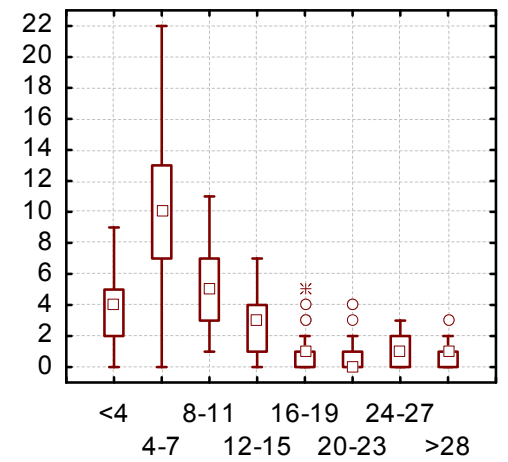

6

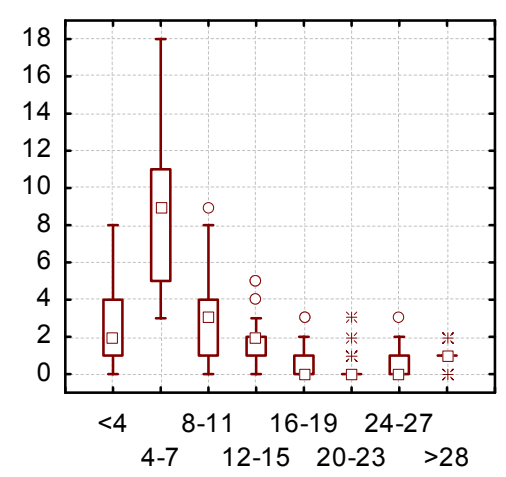

$\partial$
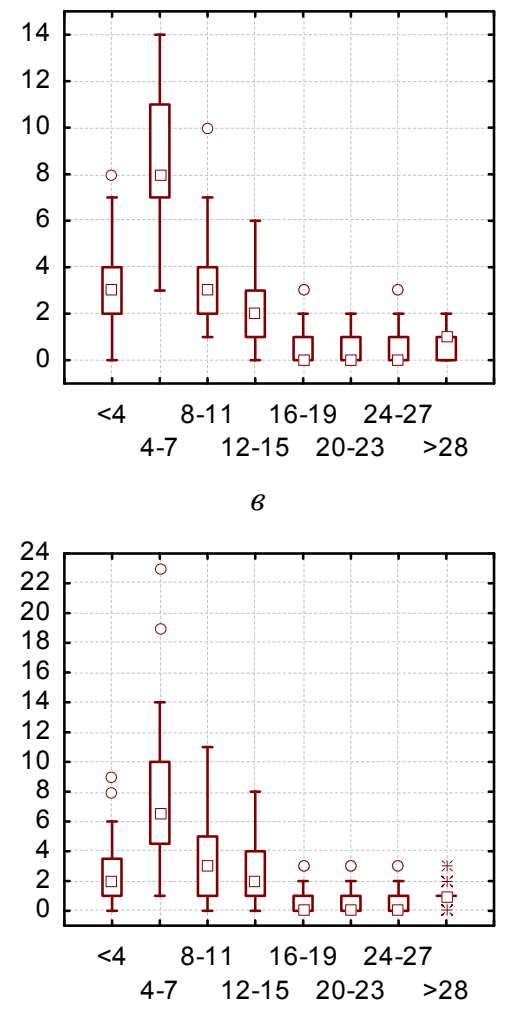

$e$

Рис. 14. Розмірна структура підстилкової мезофауни широколистяних лісів степової зони залежно від сумарного покриття трав'яного ярусу: $a$ - сумарне покриття трав'яного ярусу $<15 \%, \sigma-15-29 \%$, , $-30-44 \%$, z-45-59\%, $\partial-60-74 \%, e-75-89 \%, ж-90-100 \%$; по осі абсцис довжина тіла особин (мм), по осі ординат - кількість видів даної розмірної групи в угрупованні

За висловом давньогрецького філософа Аристотеля, «Natura ablwrret vacuum» - «Природа не терпить пустоти». Видовий склад конкретної лісової екосистеми може змінюватися, але незаповненої ніші (трофічної, розмірної чи будь-якої іншої), як правило, не залишається. Конкуренція між видами за ресурси середовища у лісах степової зони надзвичайно напружена, вона забезпечує підтримання сталості основних характеристик угруповань тваринних організмів підстилки (Brygadyrenko, 2014).

У степовій зоні ця конкуренція посилюється за рахунок того, що лісова екосистема в цілому перебуває в умовах «географічної невідповідності» умовам місцеперебування (Belgard, 1971), межує із зональною степовою або азональною лучною рослинністю, яка проникає під лісовий намет разом із притаманними для неї видами безхребетних тварин (Kulbachko et al., 2011). Отже, безхребетні тварини лісу конкурують у степовій зоні не лише між собою, а і з іншими видами, не характерними для лісів. Територіальне розташування лісової рослинності по балках і долинах річок у Степу у багато разів посилює екотонний вплив на лісову підстилкову мезофауну, а порушення зв'язків між лісами, їх «острівне розташування» не дозволяє тваринам ефективно мігрувати між окремими екосистемами (Didham, 1997; Hanski, 1999). Більшість лісів степової зони не перебувають у клімаксовому стані, зазнають впливу людини, їх видовий склад збагачується адвентивними видами, а отже, i мезофауна таких екосистем поступово змінюється (Butterfield and Malvido, 1992; Bulakhov et al., 2003; Pakhomov et al., 2011). Зміни структури підстилкової мезофауни відбуваються не тільки на нижніх щаблях трофічного ланцюга (на рівні фітофагів і сапрофагів). Вплив посилюється на другому, третьому та четвертому рівнях консументів (зоофаги першого та другого порядків, поліфаги). За даними різних авторів, в окремих випадках відбувається посилення відмінностей між еталонними та трансформованими екосистемами на вищих рівнях трофічної мережі (Rainio and Niemela, 2003; Oxbrough et al., 2005; Pearce and Venier, 2006; Talbot et al., 2008; Cameron and Leather, 2012; Slipinski et al., 2012). 


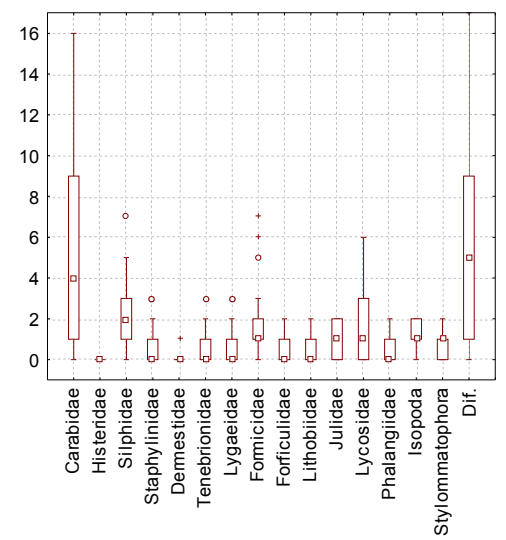

$a$

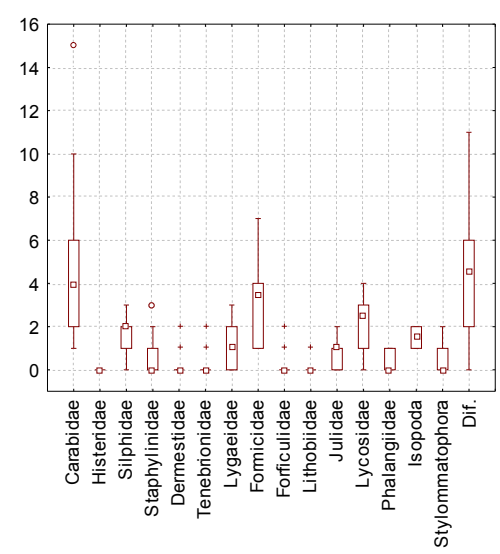

2

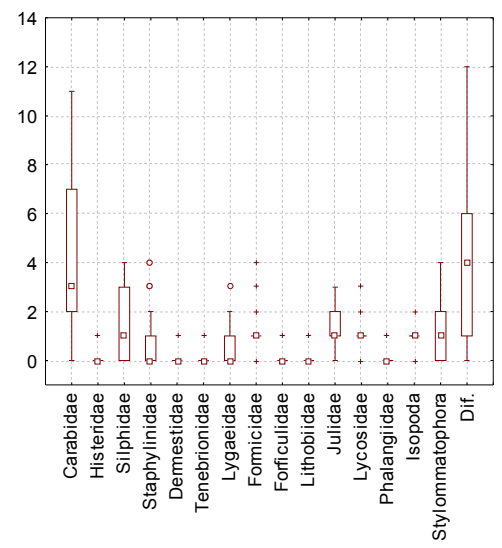

Ж

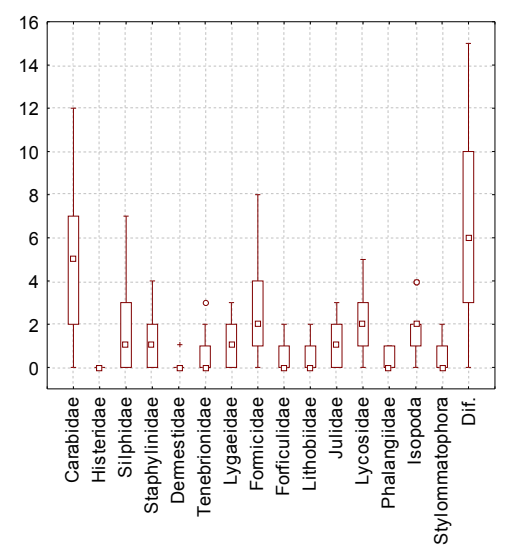

$\sigma$

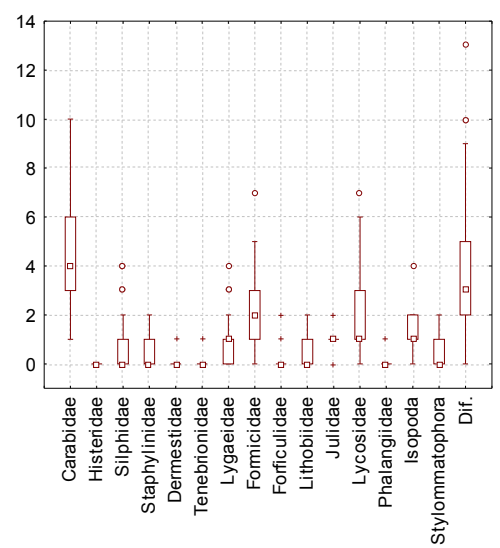

$\partial$

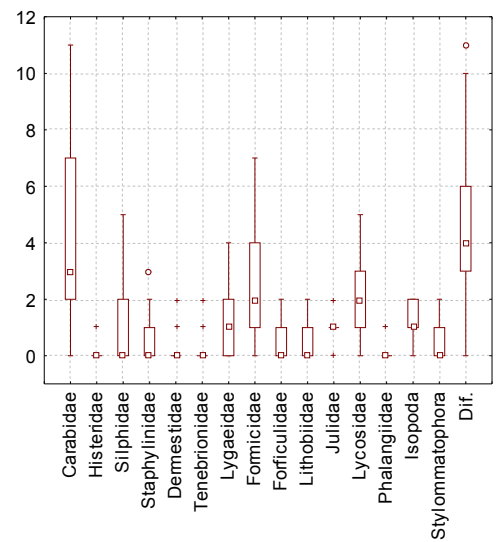

6

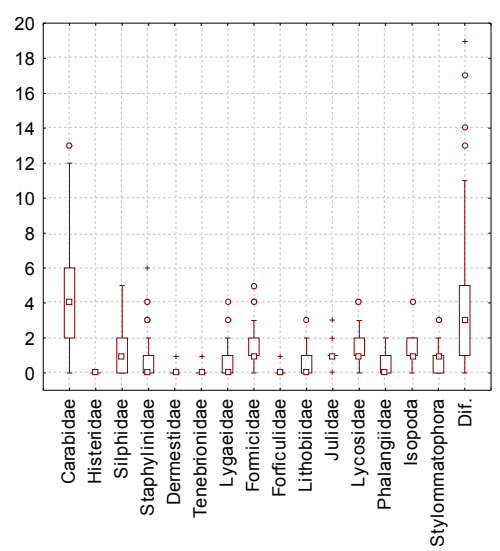

$e$

Рис. 15. Таксономічна структура підстилкової мезофауни широколистяних лісів степової зони залежно від сумарного покриття трав'яного ярусу: $a$ - сумарне покриття трав'яного ярусу $<15 \%, \sigma-15-29 \%$, , $-30-44 \%$, z-45-59\%, $\partial-60-74 \%, e-75-89 \%, ж-90-100 \%$; по осі абсцис домінантні таксономічні групи, по осі ординат - кількість видів даної групи в угрупованні; Dif. - види інших таксономічних груп

Отже, виявлені у цій статті закономірності формування угруповань безхребетних тварин ілюструють фундаментальні принципи побудови багатовидових угруповань живих організмів: стабільність угруповання в цілому за умов випадкової мінливості окремих його елементів. Механізм, який забезпечує таку стабільність, - конкуренція за ресурси середовища, поєднана 3 високими міграційною здатністю та темпами розмноження.

\section{Висновки}

Зімкненість крон дерев достовірно не впливає на чисельність підстилкової мезофауни та кількість видів безхребетних у підстилці. Індекси різноманіття Шеннона та Пілоу мають тенденцію до підвищення у градієнті зім- кненості крон дерев (від менше 50\% до 90-100\%), їх медіана зростає з 1,5 до 3,5 та 3 0,34 до 0,82 біта відповідно.

Відносна чисельність сапрофагів і зоофагів мінімальна (медіана $18 \%$ та $3 \%$ ) у лісових екосистемах із розрідженим наметом, має тенденцію до зростання у лісах із зімкненим деревостаном (40\% та $18 \%)$. Відносна чисельність поліфагів у мезофауні, навпаки, за цих умов зменшується з $82 \%$ до $27 \%$. Кількість видів кожної трофічної групи достовірно не змінюється у градієнті зімкненості крон дерев у широколистяних лісах степової зони.

У крайніх варіантах (за умов розрідженого намету із зімкненістю менше $50 \%$ та ущільненого деревостану із зімкненістю понад 90\%) дослідженого градієнта спостерігається трансформація структури домінування угруповання підстилкової мезофауни. Оптимальна структура домінування зареєстрована за умов зімкненості крон 70-79\%. 
За умов 70-79\% зімкненості крон дерев розмірна структура підстилкової мезофауни також наближається до оптимальної.

Кількість видів мурах досягає максимуму (медіана 4 види) в умовах розрідженого деревного намету (5059\%). Відносна чисельність мурах у підстилковій мезофауні максимальна (73\%) також у розріджених деревостанах (менше 50\%), відносна частка Isopoda максимальна (медіана 40\%) також в умовах розрідженого деревного намету (50-59\%). За умов зімкнених деревостанів таксономічна структура на рівні рядів і родин стає більш вирівняною, у ній зникають домінанти 3 відносною чисельністю понад 15\%. Відносна чисельність більшості

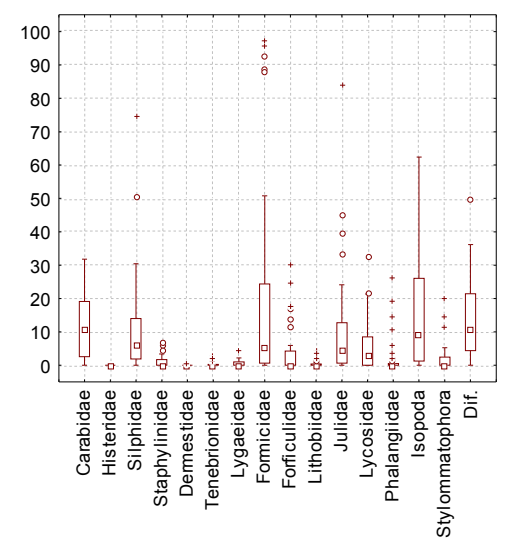

$a$

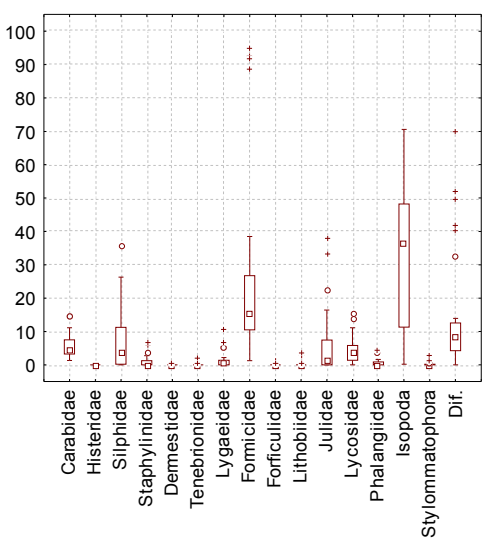

2

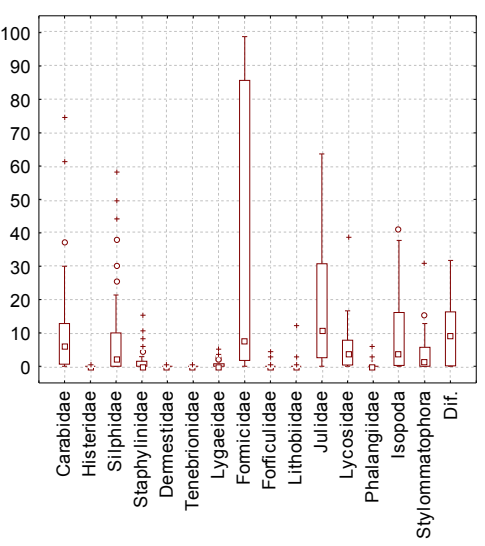

ЖC домінантних родин і рядів у градієнті зімкненості крон дерев достовірно не змінюється.

Чисельність мезофауни підстилки широколистяних лісів максимальна за умов двох крайніх варіантів розвитку трав'яного ярусу: фрагментарний трав'яний ярус (покриття менше 15\%) та щільний травостій (покритя 90-100\%). Мінімальна чисельність підстилкової мезофауни реєструється за умов середнього покриття трав'яними рослинами (45-59\%). Кількість видів, індекси різноманіття Шеннона та Пілоу достовірно не змінюються у градієнті покриття грунту трав'яними рослинами у широколистяних степових лісах.

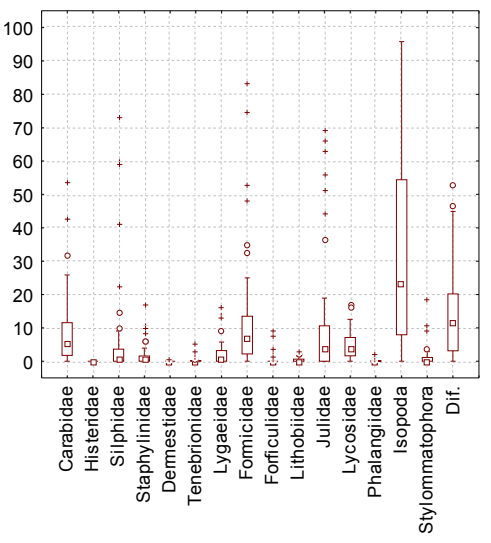

$\sigma$

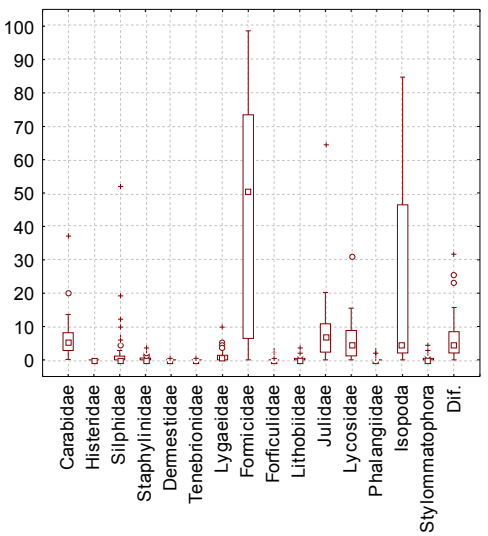

$\partial$

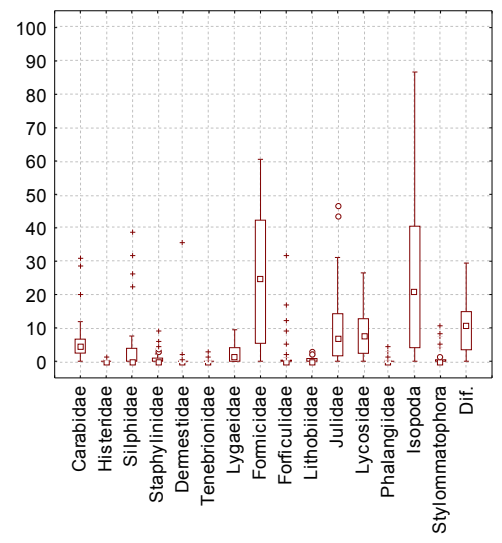

B

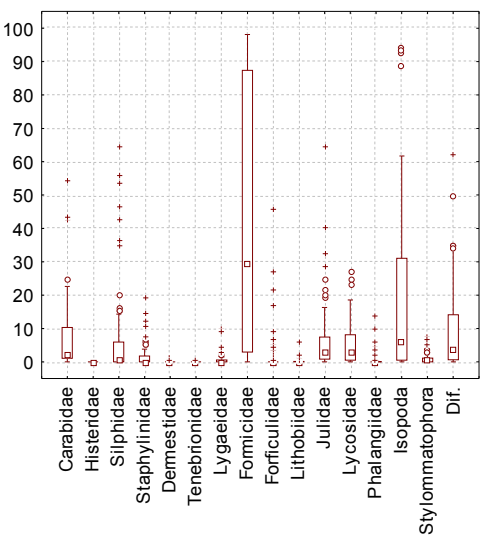

$e$

Рис. 16. Таксономічна структура підстилкової мезофауни широколистяних лісів степової зони залежно від сумарного покриття трав'яного ярусу: $a$ - сумарне покриття трав'яного ярусу $<15 \%, \sigma-15-29 \%, \varepsilon-30-44 \%$, z-45-59\%, $\partial-60-74 \%, e-75-89 \%, ж-90-100 \%$; по осі абсцис домінантні таксономічні групи, по осі ординат - частка даної групи в угрупованні за чисельністю (\%); Dif. - види інших таксономічних груп

Кількість видів фітофагів зростає в лісових екосистемах із середніми значеннями покриття трав'янистих рослин, а сапрофагів, зоофагів і поліфагів достовірно не змінюється. Частка рідкісних видів (менше 1,5\% за чисельністю) достовірно не змінюється у досліджених градаціях покриття трав'янистими рослинами. Структура 
домінування підстилкової мезофауни найбільшою мірою трансформована у крайніх варіантах розвитку трав'яного ярусу: в умовах фрагментарного трав'яного покриву (менше $15 \%$ ) та суцільного розвитку трав'яного ярусу (90-100\%).

Медіана кількості видів турунів максимальна для 15$29 \%$ покриття трав'яного ярусу. Відносна чисельність Carabidae у проаналізованих градаціях покриття трав'яної рослинності достовірно не змінюється. Медіана відносної чисельності Formicidae максимальна за умов 60-74\% покриття трав'яної рослинності, Isopoda - за 15-59\% покриття трав'яного ярусу.

\section{Бібліографічні посилання}

Bachinsky, I.Y., 1962. Klimat Ukrai'ny [The climate of Ukraine]. NAS of USSR, Kyiv (in Ukrainian).

Belgard, A.L., 1971. Stepnoje lesovedenije [Steppe Forestry]. Lesnaja Promyshlennost', Moscow (in Russian).

Brygadyrenko, V.V., 2003. Ispol'zovanie topologicheskih spektrov v zoologicheskoj diagnostike pochv na primere semejstva zhuzhelic (Coleoptera, Carabidae) [Using topological spectrums in zoological diagnostics of soils with the family Carabidae (Coleoptera) as an example]. Ecology and Noospherology 13(1), 119-130 (in Russian).

Brygadyrenko, V.V., 2004. Vozdejstvie uslovij sredy na sostav zhivotnogo naselenija podstilki i fitocenoz lesnyh ekosistem stepnoj zony Ukrainy [The influence of environmental conditions on the litter animals and phytocoenosis in the forest ecosystems of the Steppe zone of Ukraine]. Forestry and Agroforestry 106, 77-83 (in Ukrainian).

Brygadyrenko, V.V., 2006. Vozmozhnosti ispol'zovaniya napochvennyh bespozvonochnyh dlya indikacii gradaciy uvlazhneniya edafotopa $\mathrm{v}$ lesnyh ekosistemah [The possibility to use soil invertebrates to indicate soil moisture gradations in the forest ecosystems]. Vìsn. Dnìpropetr. Unìv. Ser. Bìol. Ekol. 14(1), 21-26 (in Russian).

Brygadyrenko, V.V., 2014. Influence of soil moisture on litter invertebrate community structure of pine forests of the steppe zone of Ukraine. Folia Oecol. 41(1), 8-16.

Brygadyrenko, V.V., 2015a. Vplyv umov zvolozhennja ta mineralizacii' g'runtovogo rozchynu na strukturu pidstylkovoi' mezofauny shyrokolystjanyh lisiv stepovoi' zony Ukrai'ny [Influence of moisture conditions and mineralization of soil solution on structure of litter macrofauna of the deciduous forests of Ukraine steppe zone]. Vìsn. Dnìpropetr. Unìv. Ser. Bìol. Ekol. 23(1), 50-65 (in Ukrainian).

Brygadyrenko, V.V., 2015b. Community structure of litter invertebrates of forest belt ecosystems in the Ukrainian steppe zone. Int. J. Environ. Res. 9(4), 1183-1192.

Brygadyrenko, V.V., Faly, L.I., Jakimets, K.G., 2012. Riznomanittja ugrupovan' gerpetobiju balky Tunel'na m. Dnipropetrovsk [Diversity of litter invertebrates communities from the Tunel'na Gully in Dnipropetrovsk city]. Vìsn. Dnìpropetr. Unìv. Ser. Bìol. Ekol. 20(1), 3-12 (in Ukrainian).

Brygadyrenko, V.V., Komarov, O.S., 2008. Trofichna struktura pidstylkovoji mezofauny: Rozpodil biomasy za trofichnymy rivniamy [Trophic structure of litter mesofauna: Biomass differentiation between trophic levels]. Vìsn. Dnìpropetr. Unìv. Ser. Bìol. Ekol. 16(2), 12-23 (in Ukrainian).

Brygadyrenko, V.V., Solovjov, S.V., 2007. Vplyv pervynnogo g'runtoutvorennja u zaplavnyh lisah Dniprovs'ko-Oril's'kogo pryrodnogo zapovidnyka na strukturu gerpetobiju [Effect of initial soil in floodplain forests of the Dnieper-Oril's'ke Nature Reserve on the litter invertebrates communities struc- ture]. Pynannia Bioidycacii ta Ecologii 12(1), 34-45 (in Ukrainian).

Bulakhov, V.L., Emel'janov, I.G., Pakhomov, O.Y., 2003. Bioraznoobrazie kak funkcional'naja osnova jekosistem [Biodiversity as functional basis of ecosystems]. Vìsn. Dnìpropetr. Unìv. Ser. Bìol. Ekol. 11(1), 3-8.

Butterfield, J., Malvido, J.B., 1992. Effect of mixed-species tree planting on the distribution of soil invertebrates. In: Cannell, M.G.R., Malcolm, D.C., Robertson, P.A. (Eds.) The ecology of mixed-species stands of trees, Spec. Publ. № 11. British Ecological Society, Blackwell, Oxford, 255-265.

Cameron, K.H., Leather, S.R., 2012. How good are carabid beetles (Coleoptera, Carabidae) as indicators of invertebrate abundance and order richness? Biodivers. Conserv. 21, 763-779.

Didham, R.K., 1997. An overview of invertebrate responses to forest fragmentation. In: Watt, A.D., Stork, N.E., Hunter, M.D. (Eds.), Forests and insects. Chapman \& Hall, London, 303-320.

Faly, L.I., Brygadyrenko, V.V., 2014. Patterns in the horizontal structure of litter invertebrate communities in windbreak plantations in the steppe zone of the Ukraine. J. Plant Prot. Res. 54(4), 414-420.

Fedorchenko, D.O., Brygadyrenko, V.V., 2008. Osoblyvosti formuvannia bagatovydovych ugrupovan' pidstylkovych bezchrebetnych tvaryn ostrova Khortitsa (Zaporiz'ka oblast') [Peculiarities of litter invertebrates' multispecies complexes formation on the Khortitsa island (Zaporizhzhya province)]. Vìsn. Dnìpropetr. Unìv. Ser. Bìol. Ekol. 16(2), 178-185 (in Ukrainian).

Grytsan, Y.I., 2000. Ekologichni osnovy peretvoryuyuchogo vplyvu lisovoy roslynnosty na stepove seredovysche [Ecological bases transformative impact of forest vegetation on steppe environment]. Dnipropetrovsk Univ. Press, Dnipropetrovsk (in Ukrainian).

Hanski, I., 1999. Habitat connectivity, habitat continuity, and metapopulations in dynamic landscapes. Oikos 87, 209-219.

Ivan'ko I.A., 2009. Znachennya typu svitlovoy struktury pry formuvanny shtuchnykh lisovukh biogeostenoziv u stepu [Significance of light structure in formation of planted forest ecosystems in steppe]. Pytannya lisovogo stepoznavstva ta lisovoy rekultivatsyi zemel 38, 59-64 (in Ukrainian).

Jabin, M., Mohr, D., Kappes, H., Topp, W., 2004. Influence of deadwood on density of soil macro-arthropods in a managed oak-beech forest. Forest Ecol. Manag. 194(1-3), 61-69.

Kulbachko, Y., Loza, I., Pakhomov, O., Didur, O., 2011. The zoological remediation of technogen faulted soil in the industrial region of the Ukraine Steppe zone. Behnassi, M. et al. (eds.), Sustainable agricultural development. Springer Science + Business Media, Dordrecht, Heidelberg, London, New York, 115-123.

Moroz, K.O., Brygadyrenko, V.V., Pakhomov, A.Y., 2011. Formirovanije fauny napochvennykh bespozvonochnykh peschanoj terrasy r. Orel' v uslovijakh pirogennoj sukcessii [Litter invertebrates fauna formation of the sandy terrace of Orel' river in condition of post-fire succession]. Proc. of the Azerbaijan Soc. of Zool. 3, 423-435 (in Russian).

Oxbrough, A., Gittings, T., O'Halloran, J., Giller, P.S., Smith, G.F., 2005. Structural indicators of spider communities across the forest plantation cycle. Forest Ecol. Manag. 212, $171-183$.

Pakhomov, O.Y., Gasso, V.Y., Goloborodko, K.K., Poljakov, M.V., Grycan, Y.I., Bulakhov, V.L., Brygadyrenko, V.V., Kljuchko, Z.F., Mezhzherin, S.V., Novicky, R.O., Pysanec, Y.M., Pljushh, I.G., Ponomarenko, O.L., Puchkov, O.V., Radchenko, V.G., 2011. Chervona knyga Dnipropetrovskoi oblasti. Tvarynnyj svit [The red book of Dnipropetrovsk region. Animals]. New Print, Dnipropetrovsk (in Ukrainian).

Pearce, J.L., Venier, L.A., 2006. The use of beetles (Coleoptera: Carabidae) and spiders (Araneae) as bioindicators of 
sustainable forest management: A review. Ecol. Indic. 6, 780-793.

Pielou, E.C., 1977. Mathematical Ecology. John Wiley \& Sons, New York.

Rainio, J., Niemela, J., 2003. Ground beetles (Coleoptera: Carabidae) as bioindicators. Biodivers. Conserv. 12, 487-506.

Reynolds, B.C., Crossley Jr., D.A., Hunter, M.D., 2003. Response of soil invertebrates to forest canopy inputs along a productivity gradient. Pedobiologia 47, 127-139.

Shannon, C.E., Weaver, W., 1949. The mathematical theory of communication. University of Illinois Press, Urbana.

Slipinski, P., Zmihorski, M., Czechowski, W., 2012. Species diversity and nestedness of ant assemblages in an urban environment. Eur. J. Entomol. 109(2), 197-206.
Sobek, S., Steffan-Dewenter, I., Scherber, C., Tscharntke, T., 2009. Spatiotemporal changes of beetle communities across a tree diversity gradient. Divers. Distrib. 15, 660-670.

Stamps, W., Linit, M., 1997. Plant diversity and arthropod communities: Implications for temperate agroforestry. Agroforest. Syst. 39(1), 73-89.

Talbot, T.R., Cobb, N.S., Whitham, T.G., 2008. Arthropod community diversity and trophic structure: A comparison between extremes of plant stress. Ecol. Entomol. 33(1), 1-11.

Надійшла до редколегї 29.07.2015 